\title{
Taxonomy of Late Jurassic diplodocid sauropods from Tendaguru (Tanzania)
}

\author{
Kristian Remes \\ Bereich Paläontologie, Steinmann-Institut für Geologie, Mineralogie und Paläontologie, Universität Bonn, Nussallee 8, 53115 Bonn, Germany. \\ E-mail: kristian.remes@uni-bonn.de
}

Received 23 May 2008

Accepted 23 August 2008

Published 20 February 2009

\section{Key Words}

\author{
Sauropoda \\ Diplodocoidea \\ Flagellicaudata \\ Barosaurus \\ Tornieria \\ Australodocus \\ taxonomy \\ dinosaur fauna
}

\begin{abstract}
The Late Jurassic (Tithonian) Tendaguru Beds of Tanzania yielded one of the richest sauropod faunas known, including the diplodocines Tornieria africana (Fraas, 1908) and Australodocus bohetii Remes, 2007, the only known representatives of their group on the southern continents. Historically, the holotypes and referred material of both taxa plus dozens of additional specimens had been subsumed under the term "Barosaurus africanus" (Fraas, 1908). Here, the taxonomic status of the referred elements is reviewed by evaluating the phylogenetic information content of their anatomical characters, in order to provide a firm footing for further studies (e.g. of morphometrics, histology, and phylogeny of the Tendaguru sauropods). Some of the material shows diplodocine synapomorphies and may belong to either Tornieria or Australodocus, while other specimens are diagnostic only on higher taxonomic levels (Diplodocidae, Flagellicaudata, or Diplodocoidea indet.). The isolated limb elements in most cases lack phylogenetically diagnostic characters. Generally, the "Barosaurus africanus" sample shows a substantial grade of morphological variation, and it cannot be ruled out that there are more flagellicaudatans represented in the Tendaguru material than the diplodocines and dicraeosaurids already known.
\end{abstract}

\section{Introduction}

The fossil vertebrate locality of Tendaguru, Tanzania, East Africa, is renowned for its rich Late Jurassic (Tithonian), sauropod-dominated dinosaur fauna. More than 250 tonnes of fossil material were excavated by the German Tendaguru Expedition (GTE) of 19091913 and shipped to Berlin. In this respect, the GTE was one of the greatest efforts in paleontological fieldwork ever (Maier 2003). Among this wealth of material, currently seven sauropod species in six genera (Australodocus bohetii Remes, 2007; Brachiosaurus brancai Janensch, 1914; Dicraeosaurus sattleri Janensch, 1914; D. hansemanni Janensch, 1914; Janenschia robusta (Fraas, 1908); Tendaguria tanzaniensis Bonaparte et al., 2000; Tornieria africana (Fraas, 1908)) are recognized. Tornieria africana and Australodocus bohetii (both formerly referred to as "Barosaurus africanus" Janensch, 1922) are of special interest, since these forms are the only known representatives of the sauropod family Diplodocidae on the southern continents. Originally, more than 630 elements have been assigned to "Barosaurus africanus" (Janensch, unpublished GTE field catalogue;
1929), but today about $75 \%$ of this material is lost, mainly due to the destruction of a collection room of the Museum für Naturkunde in Berlin during World War II. The remaining material has been reviewed by the author, in order to find answers for two central questions: First, what is the phylogenetic position of "Barosaurus africanus", and second, can all the material assigned to this taxon indeed be referred to the same species?

The first question aimed at the long-lasting assignment of the material to the North American genus Barosaurus Marsh, 1890 (Janensch 1922, 1929, 1935-36, 1961; Russell et al. 1980), the appropriateness of which was doubted recently (McIntosh 1990a, 1990b, 2005; Harris \& Dodson 2004; Remes 2004; Upchurch et al. 2004a). Remes (2006) argued for the generic difference to Barosaurus by providing a revised diagnosis for Tornieria africana (based on the holotype [skeleton A], and the material that can be referred to the same species: skeleton $\mathrm{k}$ and some isolated cranial caudal vertebrae). However, Remes (2006) agreed with the phylogenetic position of Tornieria within the same subfamily as Barosaurus and Diplodocus Marsh, 1878, the Diplo- 
docinae, based on several synapomorphic characters, e.g. the presence of diapophyseal laminae and pleurocoels in the cranial caudal vertebrae. In course of the examination of the "Barosaurus africanus" material, the author also recognized two cervical vertebrae that are anatomically deviant from the known cervical vertebrae of Tornieria africana, and described them as the holotype of the new genus and species Australodocus bohetii (Remes 2007).

The paper at hand deals with the remaining material originally assigned to "Barosaurus africanus" by describing its phylogenetic information content, stratigraphic occurrence, and available taphonomic data. By doing so, an overview over the quality of the material and taxonomical problems is given, summarizing what we actually can know about the Tendaguru diplodocids. This is important because the original descriptions of "Barosaurus africanus" by Janensch (1935-36, 1961) still serve as the primary source of anatomical data for the Tendaguru sauropods, and false taxonomic assignments may lead to substantial misinterpretations in further analyses (e.g., of phylogeny or histology). Recent descriptions of newly discovered diplodocoids (Carvalho et al. 2003; Harris \& Dodson 2004; Salgado et al. 2006; Harris 2006a, 2006b, 2007) and phylogenetic studies (Upchurch 1998; Wilson 2002; Salgado et al. 2004; Upchurch et al. 2004a; Rauhut et al. 2005; Harris 2006c; Salgado et al. 2006) provide a better database for assessing the taxonomic status of individual fossils. The material can be divided into two groups: a) diplodocoid material with phylogenetically diagnostic characters, and b) material that is not diagnostic beyond Sauropoda indet.

Abbreviations. GTE, German Tendaguru Expedition (1909-1913); MB, Museum für Naturkunde der Humboldt-Universität zu Berlin, Berlin; SMNS, Staatliches Museum für Naturkunde, Stuttgart.

\section{Localities and taphonomy}

The material under discussion here exclusively comes from the Late Jurassic (Tithonian; Aberhan et al. 2002) Tendaguru Beds of the Lindi District, Tanzania, East Africa. The Tendaguru Beds are composed of a ser- ies of fine sandstones, siltstones, and mudstones deposited in a coastal plain ("Saurian Beds"), with intercalations of shallow marine sandstones (Table 1; Janensch 1914b; Aberhan et al. 2002). Most of the diplodocid material comes from the Upper Saurian Beds, but two sites of the Middle Saurian Beds (labeled "dd" and "St") also yielded fossils with diplodocid characters. The base of the Upper Saurian Beds, above the marine Trigonia smeei Beds, is addressed as Upper Transitional Sands (Aberhan et al. 2002), and also yielded a number of fossil occurrences.

In total, there are 27 different localities in the Tendaguru area where material assigned to Barosaurus africanus was found (Janensch 1925a; Fig. 1). These localities fall into three different groups: (1) localities that yielded partly articulated, incomplete skeletons or skeletal parts of a single individual, (2) accumulations of more than one taxon including partly articulated or associated diplodocid material, and (3) unassociated bones, primarily in bone beds, but also at sites that yielded skeletons of other taxa, and completely isolated elements. The following comments on these localities are based primarily on Janensch (unpublished GTE field catalogue); additional references are cited in the text.

The first group is represented by the localities A, C, e, K, k, and 28, all in the Upper Saurian Beds. Locality A is the type locality of Tornieria africana, discovered by E. Fraas in 1907, and yielded an incomplete, but partially articulated skeleton consisting of the dorsal and caudal vertebral column, a partial forelimb, and the hind limb (Fraas 1908; Remes 2006). C was situated within $150 \mathrm{~m}$ next to the type locality and produced an articulated caudal vertebral column, four articulated cervical vertebrae, and some elements of the appendicular skeleton. Fraas extracted one caudal vertebra and depicted it (Fraas 1908: fig. 7), but the remaining material was excavated only later by the GTE. Most of the material from locality $\mathrm{C}$ has been destroyed, except for a right tibia (MB.R.2580 [C 13]). Locality e yielded a scapula, a sacrum, and an incomplete left pelvis and hind limb, of which the pubis (e 16) and the femur (MB.R.2671 [e 2]) are still preserved. Similarly, the partial skeleton $\mathrm{K}$ was composed of some cranial caudal vertebrae, the pelvis, and both hind limbs, of which eight vertebral centra, both tibiae (MB.R.2599 and MB.R.2594 [K 1a, K 3]), and the right fibula and astragalus (MB.R.2626 and MB.R.2564 [K 1b, K 1c]) are still in the Museum für Naturkunde collections. Locality $\mathrm{k}$ yielded the most complete skeleton of Tornieria africana, consisting of the braincase, a fairly complete vertebral column up to the mid-caudals, ribs, and all appendicular elements except manus and pes (Remes 2006). Although most axial and some appendicular elements were lost, skeleton $\mathrm{k}$ still remains the most complete specimen of Tornieria (Remes 2006). Finally, MB.R.2370 (Nr. 28) is an isolated find of an articulated left foot with astragalus.

Multi-taxon accumulations with articulated or at least associated material later referred to "Barosaurus africanus" include G, Z, XIII, and XVII in the Upper Saurian Beds, F, H, and Ki in the Upper Transitional Sands, and dd in the Middle Saurian Beds. Locality G was situated next to $\mathrm{A}$, e, and $\mathrm{F}$, and yielded 98 skeletal elements of at

Table 1. Simplified overview of the stratigraphy of the Tendaguru Beds. After Aberhan et al. (2002).

\begin{tabular}{|c|c|c|}
\hline Unit & Age & Thickness \\
\hline Trigonia schwarzi Beds & $\begin{array}{l}\text { Early Cretaceous } \\
\text { (?Valanginian-?Hauterivian) }\end{array}$ & $>5 \mathrm{~m}$ \\
\hline $\begin{array}{l}\text { Upper Saurian Beds } \\
\text { Base: Upper Transitional Sands }\end{array}$ & Tithonian & $33 \mathrm{~m}$ \\
\hline Trigonia smeei Beds & Early Tithonian & $30 \mathrm{~m}$ \\
\hline $\begin{array}{l}\text { Top: Lower Transitional Sands } \\
\text { Middle Saurian Beds } \\
\text { Base: Transitional Sands above Nerinea Beds }\end{array}$ & $\begin{array}{l}\text { ?Late Kimmeridgian } \\
\text { ?Early Tithonian }\end{array}$ & $14 \mathrm{~m}$ \\
\hline Nerinea Beds & Late Kimmeridgian, possibly older & $22 \mathrm{~m}$ \\
\hline Lower Saurian Beds & ?Oxfordian-Kimmeridgian & $>11 \mathrm{~m}$ \\
\hline
\end{tabular}




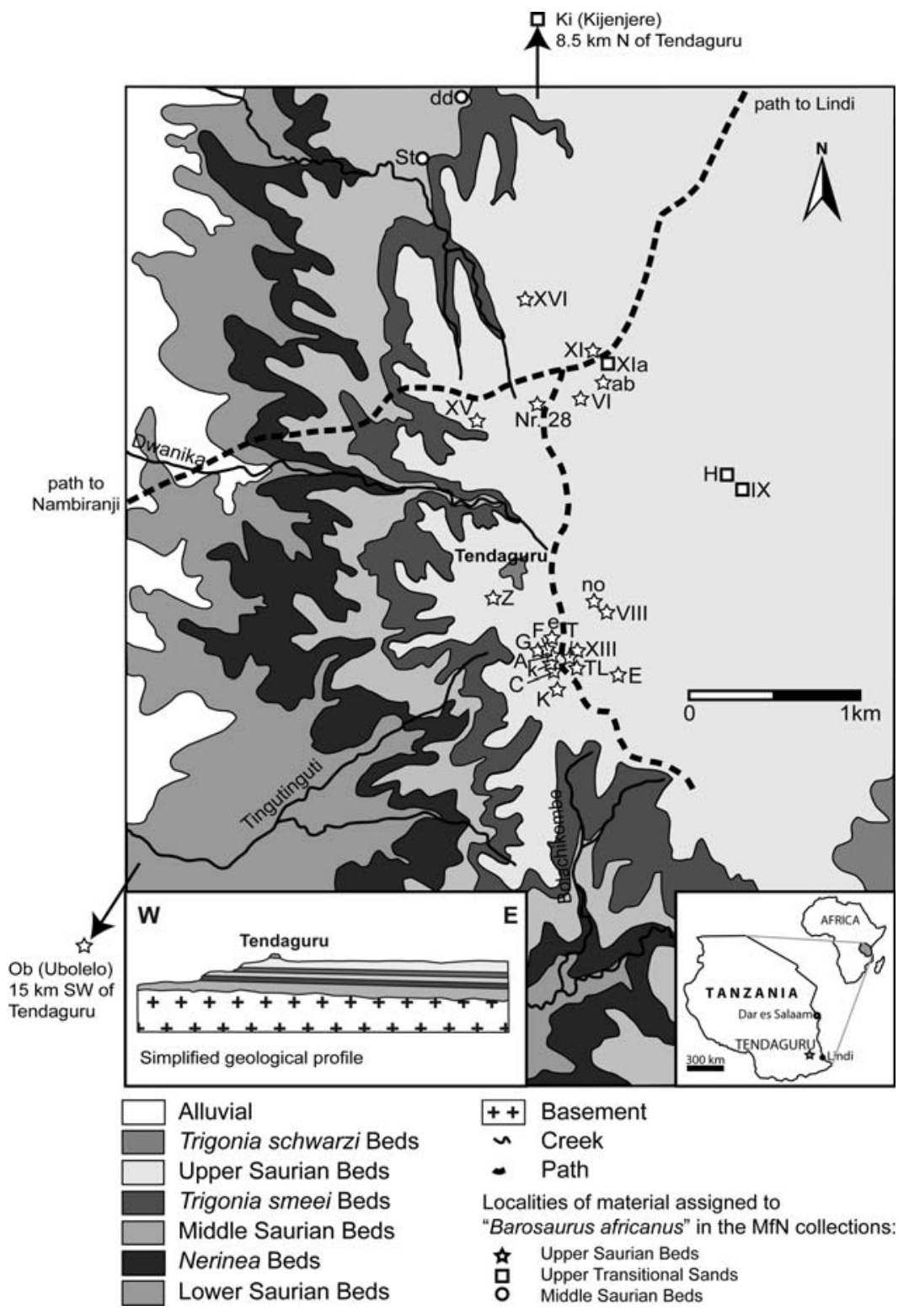

Figure 1. Geological map of the Tendaguru area showing the GTE sites that yielded material later assigned to "Barosaurus africanus" (Fraas, 1908). The bedding of the Tendaguru Beds and the geographical location within Africa is indicated in the insets. Redrawn after Janensch (1914, 1925a) and Aberhan et al. (2002)

least four different genera, the identity of which is not specified in the GTE field catalogue. In the MB collections, only two cervical vertebra and two humeri from this site were referred to "Barosaurus africanus". Bonaparte et al. (2000) described a partial vertebral column of Janenschia robusta from this site, but the rest of the material is lost. The two cervical centra have been referred to the new taxon Australodocus bohetii (Remes 2007). At locality Z, situated at the southern base of Tendaguru Hill, a partially articulated pelvis and a caudal vertebral column was excavated, as well as many isolated limb elements of various taxa. The caudal vertebrae were identified as "Barosaurus africanus", and there are still three of them present in the MB collections [Z 15, 27, and 37]. Locality XIII was a digging trench east of the Tornieria type locality A that yielded isolated sauropod limb elements, theropod vertebrae, and an articulated right pes of diplodocid affinity (MB.R.2371 [XIII 10]), similar to find MB.R.2370 (Nr. 28). The original position of trench XVII is unknown; at this site, only few hind limb elements and two humeri of at least two individuals were recovered. $\mathrm{F}$ is the label for an assemblage of nine elements, one pubis and eight limb bones, which were discovered in trench VII, and have been regarded as belonging to a single individual (Janensch, unpublished GTE field catalogue). Excavation site $\mathrm{H}$ yielded paired pubes, ischia, femora, and fibulae, as well as additional unpaired elements of the fore- and hind limb, and ribs.
Heinrich (1999: fig. 12) depicted the taphonomy of this find. At first glance, these elements seem to represent only one individual, but Heinrich (1999) recognized a 7.5\% size difference between both femora, which can also be found in the other paired elements $(3-6 \%$, pers. obs.). These high differences indicate that $\mathrm{H}$ is at least a multiindividual, and possibly also a multi-taxon assemblage (Heinrich 1999; see below). Locality Ki (Kijenjere) is the northern-most excavation site on the Tendaguru Plateau, about $8.5 \mathrm{~km}$ north of Tendaguru Hill (Janensch 1925a). Which horizon cropped out at Ki was not clear in the first place (Janensch, unpublished GTE field catalogue; 1929), but later the site has been regarded as Upper Transitional Sands (Janensch 1961). Russell et al. (1980) listed $\mathrm{Ki}$ as being situated in the Lower Transitional Sands, but gave no justification for the change. There is no taphonomic data for the originally 130 elements excavated by the GTE at $\mathrm{Ki}$, which include various sauropod vertebrae, associated diplodocid skull elements, and remains of the stegosaur Kentrosaurus Hennig, 1915. Finally, one of two sites in the Middle Saurian Beds that yielded material referred to "Barosaurus africanus" is trench dd, about $2.5 \mathrm{~km}$ north of Tendaguru Hill (Fig. 1). This site was one of the largest and richest digging trenches: more than 500 sometimes articulated but mostly disarticulated elements of all Tendaguru sauropods except Janenschia and Tendaguria were recovered. Most notably, two braincases referred to "Barosaurus africanus" and 
a number of caudal vertebrae of Tornieria africana (Remes 2006) were found. Sporadically, trench dd also yielded elements of other faunal elements, for example theropods (Janensch 1920, 1925b). There are no quarry maps of dd preserved.

All remaining elements labeled "Barosaurus africanus" in the MB collections are isolated bones from the following sites: ab, E, no, NAGD, NW, Ob (Ubolelo, about $15 \mathrm{~km} \mathrm{SW}$ of Tendaguru hill), T, TE, Tec, TL, VI and VIII in the Upper Saurian Beds; IX, XI a, XV, XVI, and some elements from $\mathrm{Ki}$ in the Upper Transitional Sands; and St in the Middle Saurian Beds.

\section{Material and methods}

The diplodocid material from Tendaguru treated in this paper includes premaxillae, maxillae, a prefrontal, two braincases, a dentary, an atlantal intercentrum, two dorsal vertebrae, a sternal plate, a number of caudal vertebrae, and most elements of the appendicular skeleton, with the exception of coracoids and manual phalanges. A complete overview of the material is given in the Appendix, with references of previous mention of each element (if applicable) and comments on labeling errors. All elements were measured over straight distances (length, width) with standard tape measures and calipers.

\section{Systematic Paleontology}

The two species of diplodocid sauropods currently recognized from Tendaguru, Tornieria africana and Australodocus bohetii, have been described in detail by Remes $(2006,2007)$. Only two mid-cervical vertebrae are known from Australodocus, while Tornieria preserves the braincase, five presacral and a number of caudal vertebrae, a sternal plate, scapula, humerus, ulna, ilium, ischium, femur, tibia, fibula, and astragalus. The remaining diplodocid material originally assigned to "Barosaurus africanus", which will be described in the following, in most cases either does not overlap with the type and referred material of Australodocus and Tornieria, or is not diagnostic on genus level. The latter is especially true for isolated limb elements. Two braincases found in trench dd can be compared to the braincase of the Tornieria specimen skeleton $\mathrm{k}$, but show differences that might be due to individual variation, preservation, or true interspecific difference.

Saurischia Seeley, 1888

Sauropodomorpha Huene, 1932

Sauropoda Marsh, 1878

Diplodocoidea Marsh, 1884

Flagellicaudata Harris \& Dodson, 2004

Diplodocidae Marsh, 1884

Diplodocinae Marsh, 1884

Diplodocinae indet.

\section{Partial skull from site Ki (Kijenjere)}

The bone field in Kijenjere yielded the rostral part of a skull, comprising the left and right premaxillae
(MB.R.2346 [Ki 126], MB.R.2343 [Ki 125]), the incomplete left maxilla (MB.R.2345 [Ki 127]) and fragments of the right maxilla (MB.R.2350 [Ki 128]) (Fig. 2). The elongate premaxillae extend far caudally and taper towards their dorsal ends, which are broken off. Each premaxilla bears four alveoli. Laterally above the fourth alveolus of MB.R.2343 (Ki 125), a premature replacement tooth is visible. The elongate, slender crown of this tooth is pencil-shaped. In the maxillae, replacement teeth of identical shape are preserved. All these characters are diagnostic for Diplodocoidea (Calvo \& Salgado 1995; Upchurch 1995, 1998; Wilson 2002; Upchurch et al. 2004a; Rauhut et al. 2005; Harris 2006c; Salgado et al. 2006). Resembling Apatosaurus Marsh, 1877 and Diplodocus (Holland 1924; Berman \& McIntosh 1978), but unlike Suuwassea Harris, 2006 and Dicraeosaurus (Janensch 1935-36), the nasal process of the premaxilla is continuous with, not medially offset from the lateral side of the tooth-bearing portion of the bone. The rostroventral part of the left maxilla is broken off; six alveoli are visible caudal to the break. This part of the maxilla is relatively slender in rostrocaudal direction, again resembling diplodocids more than Dicraeosaurus. The maxilla of Suuwassea is too incomplete to be compared (see Harris 2006a). The caudal process is missing in MB.R.2343 (Ki 125), but the rostral rim of the preantorbital fenestra is preserved dorsal to the fracture surface. The rostroventral part of this rim forms a wide, medially displaced shelf, while the rostral border forms a sharp edge. This peculiar form is only known from Diplodocus (Wilson 2002), but since skulls of other diplodocines are unknown, this character could characterize all members of this group. The ascending process of the maxilla is incomplete. Its smooth caudal border indicates the rostral edge of the antorbital fenestra. Other potentially diagnostic characters, like a median narial fossa, a subnarial foramen or the rostral maxillary foramen between premaxilla and maxilla cannot be observed. Hence, it can only be concluded that these specimens belong to a form that is closely related to Diplodocus; therefore, they are referred to Diplodocinae indet.

The complete right dentary Ki 129 described as "Barosaurus africanus" by Janensch (1935-36) could not be located in the MB collections in summer 2003.

\section{Caudal vertebral column and limb elements of skeleton $K$}

Only nine cranial caudals are preserved from site K, with only one caudal being fairly complete, the others comprising only centra. Like in Tornieria, the centra exhibit deep pleurocoels in the upper third of the vertebral body, and deep ventral furrows (Remes 2006) (Fig. 3A-C). These are asymmetric and of varying shape, and in some cases are subdivided by one or two longitudinal septa. K 18 is the shortest vertebra and strongly procoelous, while $\mathrm{K} 9$ is more elongate and 


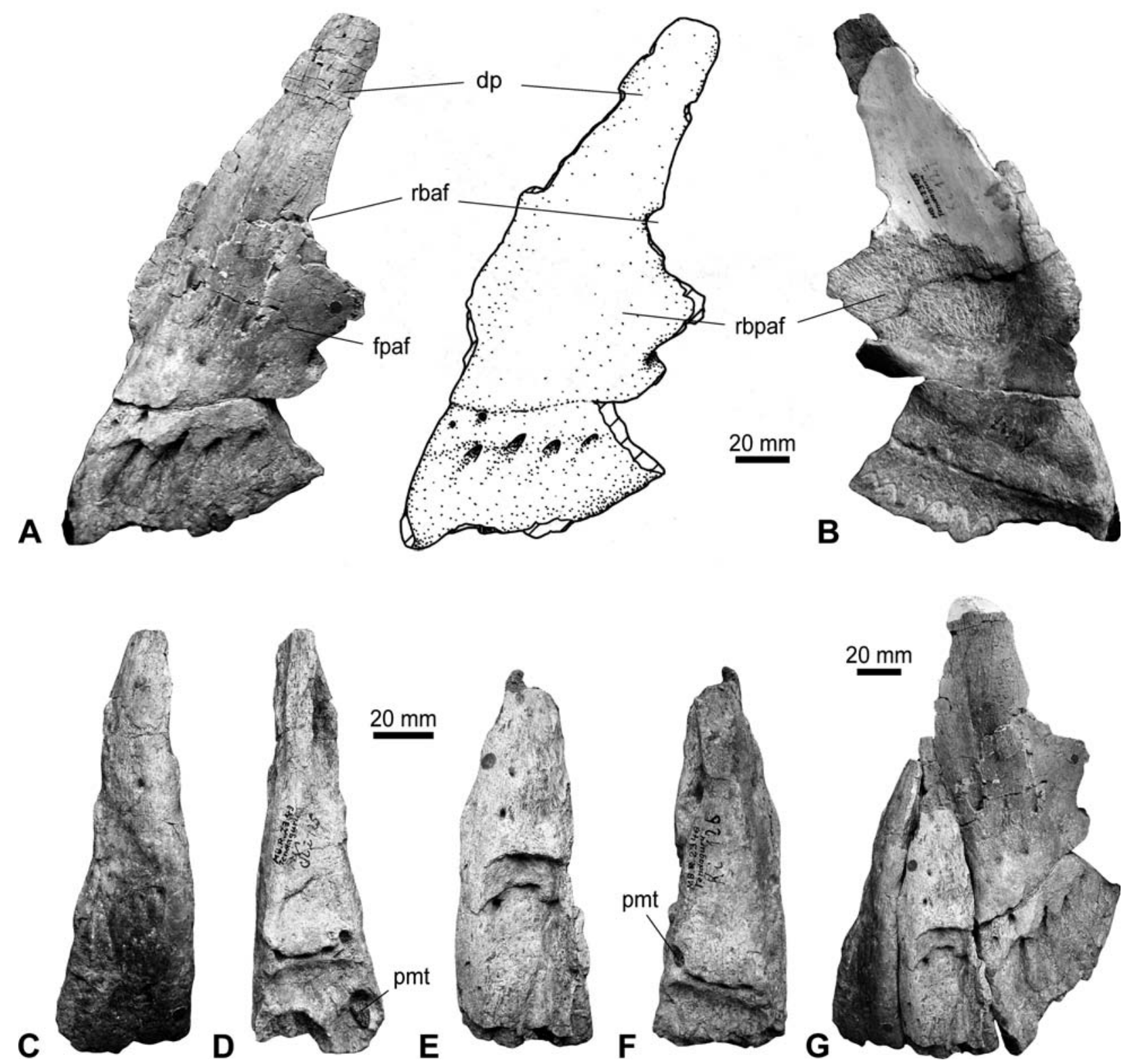

Figure 2. Partial diplodocine skull from Kijenjere (site Ki), Upper Transitional Sands of the Tendaguru Beds. A. Left maxilla MB.R.2345 (Ki 127) in lateral view; B. Medial view; C. Right premaxilla MB.R.2343 (Ki 125) in rostral view; D. Caudal view; E. Left premaxilla MB.R.2346 (Ki 126) in rostral view; F. Caudal view; G. Articulated snout region of the skull in rostrolateral view. Abbreviations: dp - dorsal process; fpaf - fossa of preantorbital fenestra; pmt - premature tooth; rbaf - rostral border of antorbital fenestra; rbpaf - rostral border of preantorbital fenestra.

has only weak ventral furrows, indicating the transition to the mid-caudal vertebrae. The exact position of these vertebrae in the caudal vertebral column is hard to determine, but comparison to Diplodocus (Hatcher 1901) implies that this series comprises caudal vertebrae 3 to 10. The presence of pleurocoels in cranial caudal vertebrae is diagnostic for Diplodocinae, and the conspicuous ventral furrows are reminiscent of Tornieria.

Site $\mathrm{K}$ also yielded a right tibia, fibula, and astragalus in articulation, but it is not known how close to the caudal vertebral column these elements were found. However, judging from the original listing of discoveries from site $\mathrm{K}$ in the GTE field catalogue (Janensch unpublished), it appears probable that all elements be- long to a single individual (see above). There is also a left tibia of the same size and form as the right tibia, which therefore probably also belongs to the same individual. Like in the Tornieria holotype, there is no medial muscle scar on the proximal end of the fibula (Remes 2006). However, the shape of this element differs from that of the corresponding element of the holotype of Tornieria africana: The proximal and distal ends are more slender, and the distal end lacks the conspicuous medial expansion seen in Tornieria (see Fig. 12B). The tibiae have also distinctly less expanded proximal and distal ends in comparison to Tornieria, the cnemial crest is larger and more distally placed, and the lateral malleolus of the distal end is more expanded than in 


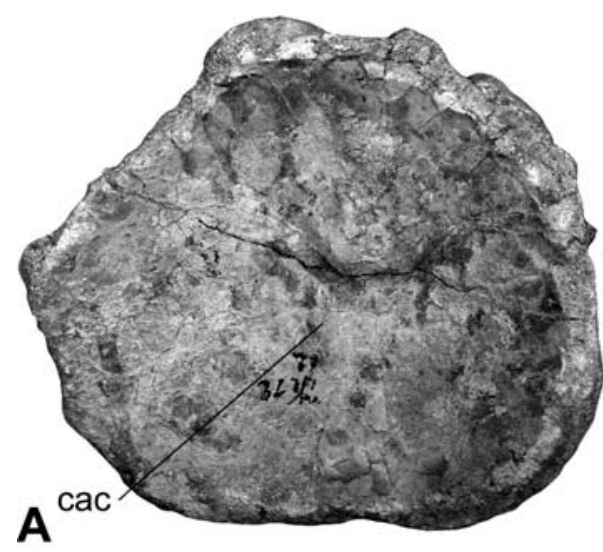

B
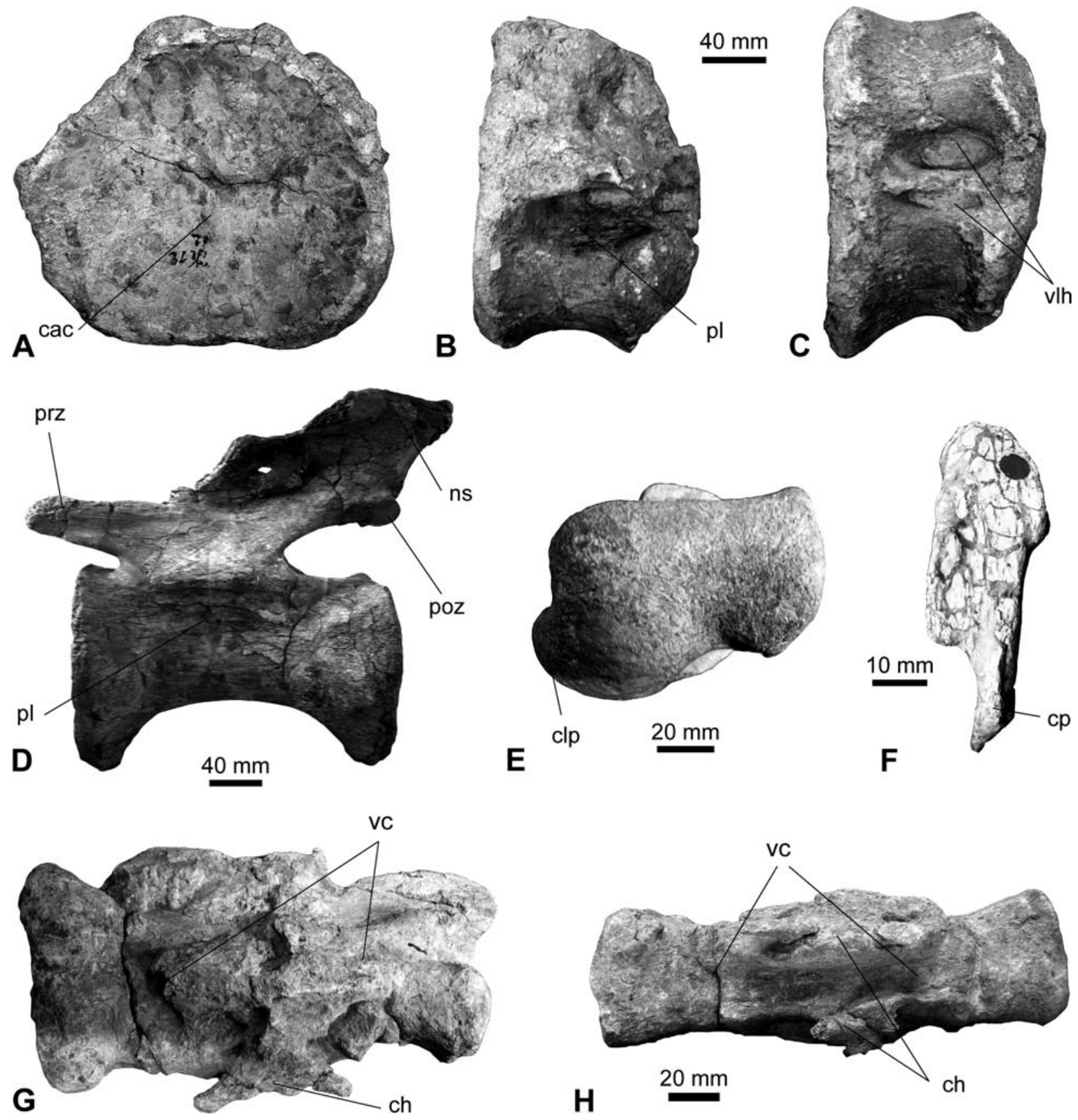

Figure 3. Specimens originally attributed to "Barosaurus africanus" (Fraas, 1908) that show diplodocine characters. A. Cranial caudal vertebra K 18 in cranial view; B. Left lateral view; C. Ventral view; D. Mid-caudal vertebra Z 15 in left lateral view; E. Left metatarsal I of pes MB.R.2371 (XIII 10) in distal view; F. Right prefrontal MB.R.2349 (dd 517) in dorsal view; G. Midcaudal vertebrae and chevrons of a juvenile diplodocine (Ki 75-77) in lateral view; H. Ventral view. Abbreviations: cac - cranial articular cavity; ch - chevrons; clp - caudolateral process; cp - caudal process of prefrontal; ns - neural spine; pl - pleurocoel; poz - postzygapophysis; prz - prezygapophysis; vc - ventral cavity; vlh - ventral longitudinal hollows.

Tornieria. The astragalus has a subtriangular shape (as compared to a more trapezoidal form in Tornieria), with a lateral articular shelf for the fibula that has its greatest width much more caudally placed than in Tornieria (see Fig. 12C). Although the cranial caudal centra closely resemble those of Tornieria, the high number of differences in the shape of the individual elements evokes doubts on the taxonomic identity of this find, which is consequently not referred to Tornieria africana, but to Diplodocinae indet. here.
Caudal vertebral column and limb elements of skeletons $Z$ and $C$

As mentioned in the 'Localities' section above, only four mid-caudal vertebrae and a tibia are preserved from the formerly much more complete partial skeletons $\mathrm{Z}$ and $\mathrm{C}$. Among the vertebral elements, Z 15 is the most complete (Fig. 3D). The centrum is elongate and strongly constricted at mid-length. As typical for diplodocines, the lateral side of the centrum is flat- 
tened, and the ventral side bears a longitudinal hollow. Dorsolaterally on the centrum, a longitudinal depression is found at mid-length below a craniocaudally wide but transversely short transverse process, which is completely absent in the other vertebrae (Z 27, Z 37, SMNS 12141b) due to a more caudal position of these elements. The transverse process in Z 15 is level with the dorsal edges of the articular facets of the centrum. The prezygapophyses are transversely compressed, cranially blunt, and project cranially far beyond the level of the cranial articular facet of the centrum. The postzygapophyses are situated directly dorsal to the caudal articular facet of the centrum. Dorsal to the postzygapophyses, the craniocaudally elongate neural spine projects only little more caudally, and bears a hook-shaped, dorsally directed tubercle on its caudal corner, a unique trait not seen in other diplodocids. The neural spine is not strictly dorsally directed like in Diplodocus (Hatcher 1901) and Barosaurus (Lull 1919; McIntosh 2005), and also lacks the cylindrical expansion of the distal end that is characteristic for the latter genus (Wilson 2002). Instead, the spine is relatively low and projects caudodorsally, which is the plesiomorphic condition and also seen in Apatosaurus (Gilmore 1936; Upchurch et al. 2004b) and Supersaurus Jensen, 1985 (Lovelace et al. 2007).

The centrum of a mid-caudal vertebra from site $\mathrm{C}$ (SMNS 12141b) is identical in shape to the vertebrae of skeleton $\mathrm{Z}$, but about $20 \%$ larger. The right tibia MB.R.2592 (C 13) is more robust than the known tibia of Tornieria (MB.R.2572 [k 41]) and the tibiae from skeleton K (MB.R.2599 [K 1a], MB.R.2594 [K 3]), and resembles the latter find in the relative size of the cnemial crest and the form of the distal articular end (see Fig. 12A). The characters of the vertebrae identify specimens Z and C as Diplodocinae (Upchurch 1998; Wilson 2002; Upchurch et al. 2004a; Rauhut et al. 2005; Harris 2006c; Salgado et al. 2006), but these elements are not diagnostic on genus level. The differences in the shape of the tibia between skeleton $\mathrm{k}$ (Tornieria) and skeleton $\mathrm{C}$ also speaks against an assignment of the material from site $\mathrm{C}$ to Tornieria, although the grade of individual variation in sauropods is not known (compare Bonnan et al. 2008). Considering these uncertainties, skeletons $\mathrm{Z}$ and $\mathrm{C}$ are both referred to Diplodocinae indet.

\section{Distal caudal vertebrae from site $K i$}

A specimen that consists of two small, fused mid-caudal vertebral centra and paired hemapophyses is labeled as $\mathrm{Ki} 75-77$ (Fig. 3G-H). The specimen was found at Kijenjere together with other small dorsal and caudal vertebrae (Janensch, unpublished GTE field catalogue) that are lost today. The vertebral centra are only weakly elongate, but have flattened lateral sides and a shallow longitudinal hollowing on their ventral side. The hemapophyses are only rudimentary developed, but show the forked shape with elongate cranial and caudal processes that is synapomorphic for Flagellicaudata (Upchurch 1998; Upchurch et al. 2004a; Harris 2006c). The threesided, ventrally concave form of the centra is typical for diplodocines (Marsh 1895; Upchurch 1998; Wilson 2002; Upchurch et al. 2004a; Rauhut et al. 2005; Harris 2006c; Salgado et al. 2006), but the grade of elongation is unusually low for this group. Since both vertebrae measure only $15 \mathrm{~cm}$ in combined length, and because the hemapophyses are only weakly developed, it may well be that specimen $\mathrm{Ki}$ 75-77 represents a juvenile individual. The presence of characters synapomorphic for Diplodocinae allows a reference to this group, but the specimen is not diagnostic on genus level.

\section{Isolated pubes from sites $E, H, X I$, and $K i$}

In total, there are six pubes in the MB collections that were attributed to "Barosaurus africanus", including specimens MB.R.2736 (E 6), e 16, H 9, H 10, MB.R.2722 (XI a 10), and MB.R.2735 (Ki 13) (see Fig. 11A). As mentioned in the 'Localities' section above, the specimens from site $\mathrm{H}$ probably do not belong to a single individual, while most of skeleton e is lost; all other specimens were found isolated. Specimens MB.R.2736 (E 6), MB.R.2722 (XI a 10), H 9, and MB.R.2735 (Ki 13) have a prominent, hook-shaped ambiens process caudodorsally. An enlarged ambiens process is a derived trait of Flagellicaudata (McIntosh 1990a; Wilson 2002; Rauhut et al. 2005; Salgado et al. 2006), but its hook-like shape is synapomorphic for Diplodocinae (Upchurch 1998; Upchurch et al. 2004a; Harris 2006c). Therefore, these four specimens may be referred to Diplodocinae indet.

\section{Diplodocoidea Marsh, 1884}

Flagellicaudata Harris \& Dodson, 2004

Diplodocidae Marsh, 1884

\section{Diplodocidae indet.}

\section{Prefrontal MB.R.2349 (dd 517)}

The prefrontal MB.R.2349 (dd 517) was found in trench dd, but was seemingly not associated with the braincases MB.R.2388 (dd 130) or MB.R.2387 (dd 316) (see below). The prefrontal is characterized by a small, triangular caudal process that tapers sharply in caudomedial direction (Fig. 3F), a derived character shared by all Diplodocidae (Upchurch 1998; Upchurch et al. 2004a; Harris 2006c). In this respect, it resembles the prefrontal of Tornieria, but the caudomedial process is much smaller and more gracile. Since the shape of this element does not exactly conform to the prefrontal of Tornieria, and because there are at least two diplodocids represented in the Tendaguru material (Remes 2007), MB.R.2349 (dd 517) cannot be referred to Tor- 


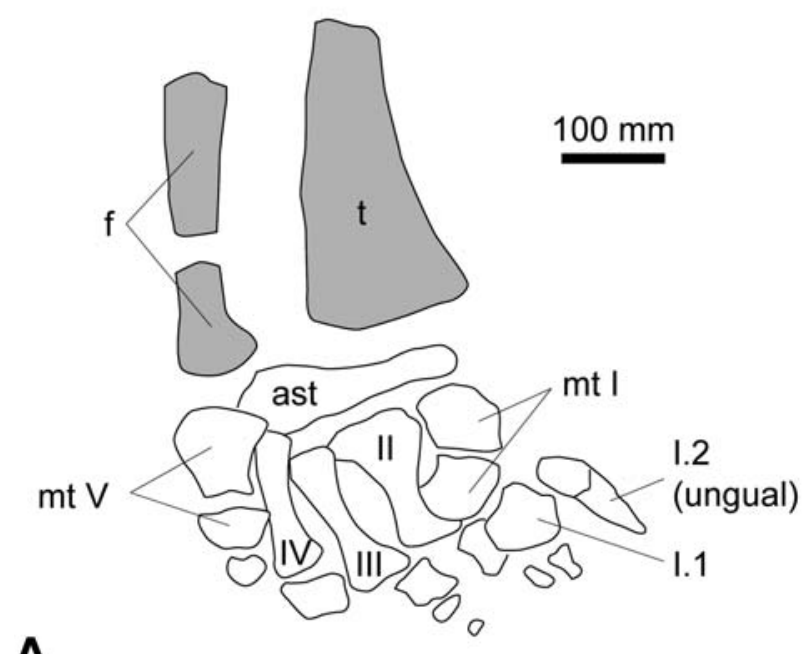

A

Figure 4. Isolated diplodocid feet from Tendaguru. A. Field sketch of MB.R.2370 (Nr. 28) before individual elements were taken out. Tibia and fibula are now lost; B. MB.R.2371 in proximal and dorsal views. Abbreviations: ast - astragalus; f - fibula; mt metatarsal; $\mathbf{t}$ - tibia; I.1 - first phalanx of digit I; I.2 - second phalanx of digit I.

nieria with confidence and is therefore addressed as Diplodocidae indet.

\section{Articulated pedes Nr. 28 and XIII 10, metatarsals from trench XVI}

Janensch (1961) described in detail two articulated foot skeletons, MB.R.2370 (Nr. 28) and MB.R.2371 (XIII 10). MB.R.2370 (Nr. 28) preserves also the astragalus, which is heavily eroded and therefore not diagnostic. In both specimens, metatarsal I exhibits a caudolateral process on the distal articular condyle (Fig. 3E), a character synapomorphic for Flagellicaudata (Berman \& McIntosh 1978; McIntosh 1990a; Upchurch 1998; Wilson 2002; Upchurch et al. 2004a; Rauhut et al. 2005; Harris 2006c; Salgado et al. 2006). Two isolated first metatarsals (MB.R.2400 [XVI 21], MB.R.2286 [XVI 28]) that show the same character are also still present in the MB collections. No calcaneum is preserved in either of both articulated feet. Since MB.R.2370 (Nr. 28) was found in situ with parts of the lower leg bones preserved (Fig. 4A), the calcaneum was obviously not ossified in this individual, a character previously regarded as synapomorphic for Diplodocidae (Upchurch 1998; Wilson 2002; Upchurch et al. 2004a; Harris 2006c). However, since an ossified calcaneum has been reported for a specimen of Diplodocus (Bonnan 2000), the presence of this element seems to pertain to individual variation. Nevertheless, missing calcanea in fully articulated feet have only been reported for diplodocids (McIntosh 1990a). Furthermore, metatarsals III and IV are the longest metatarsals (Fig. 4B), another character regarded as diagnostic for diplodocids (McIntosh 1990b). Among Diplodocidae, only Apatosaurus and Diplodocus preserve complete pedes. Apatosaurus is characterized by robust proportions and dis- tinct ligament scars distolaterally on the metatarsals (Upchurch 1995; Upchurch et al. 2004a; Upchurch et al. 2004b; Harris 2006c; see Bonnan 2005 for a functional interpretation), while these are not as prominently developed in Diplodocus and Barosaurus (Bonnan 2005). Like in the latter taxa, the elements of the Tendaguru specimens are more slender than those of Apatosaurus. Ligament scars cannot be observed. However, metatarsal V is more robustly built in the Tendaguru specimens than in Diplodocus (see Hatcher 1901; Janensch 1961). In summary, the characters observable in these foot skeletons allow to refer them to Diplodocidae, but given that at least two diplodocid genera exist in Tendaguru (Tornieria and Australodocus) that do not preserve corresponding elements, these finds cannot be referred to any specific genus. Since Janensch (1961) noted several differences in proportions in the individual elements of both feet (MB.R.2371 [XIII 10] has generally more slender elements), it is also possible that the two pedal skeletons represent two different taxa.

\section{Diplodocoidea Marsh, 1884 \\ Flagellicaudata Harris \& Dodson, 2004}

\section{Flagellicaudata indet.}

\section{Braincase MB.R.2388 (dd 130)}

Janensch (1935-36) described in detail two braincases from trench dd in the Middle Saurian Beds (see 'Localities' above), MB.R.2388 (dd 130) and MB.R.2387 (dd 316), and referred both to "Barosaurus africanus". These specimens seemingly were not associated with postcranial material, and are distinctly smaller than the known braincase of Tornieria MB.R.2386 (k 1): MB.R.2388 (dd 130) reaches only about $80 \%$ the size 
of MB.R.2386 (k 1). Both braincases differ in morphology and are therefore addressed separately here.

Like in Tornieria, the occipital condyle of MB.R.2388 (dd 130) (Figs 5, 6A-B) has rotated ventrally (its long axis being subparallel to the surface of the occiput), and the basipterygoid processes are rostrolaterally oriented, as is typical for Flagellicaudata (Calvo \& Salgado 1995; Upchurch 1998; Wilson 2002; Upchurch et al. 2004a; Harris 2006b; Salgado et al. 2006).
In contrast to Tornieria and Diplodocus, the profile of the occiput is not wide and rectangular, but distinctly more narrow and rounded, resembling Suuwassea (Harris 2006a), Dicraeosaurus (Janensch 1935-36), and Apatosaurus (Berman \& McIntosh 1978). MB.R.2388 (dd 130) preserves caudolaterally oriented paroccipital processes that have dorsally expanded, laterally slightly rounded distal ends. This has been regarded as a synapomorphic trait of Diplodocidae (Upchurch 1998; Up-
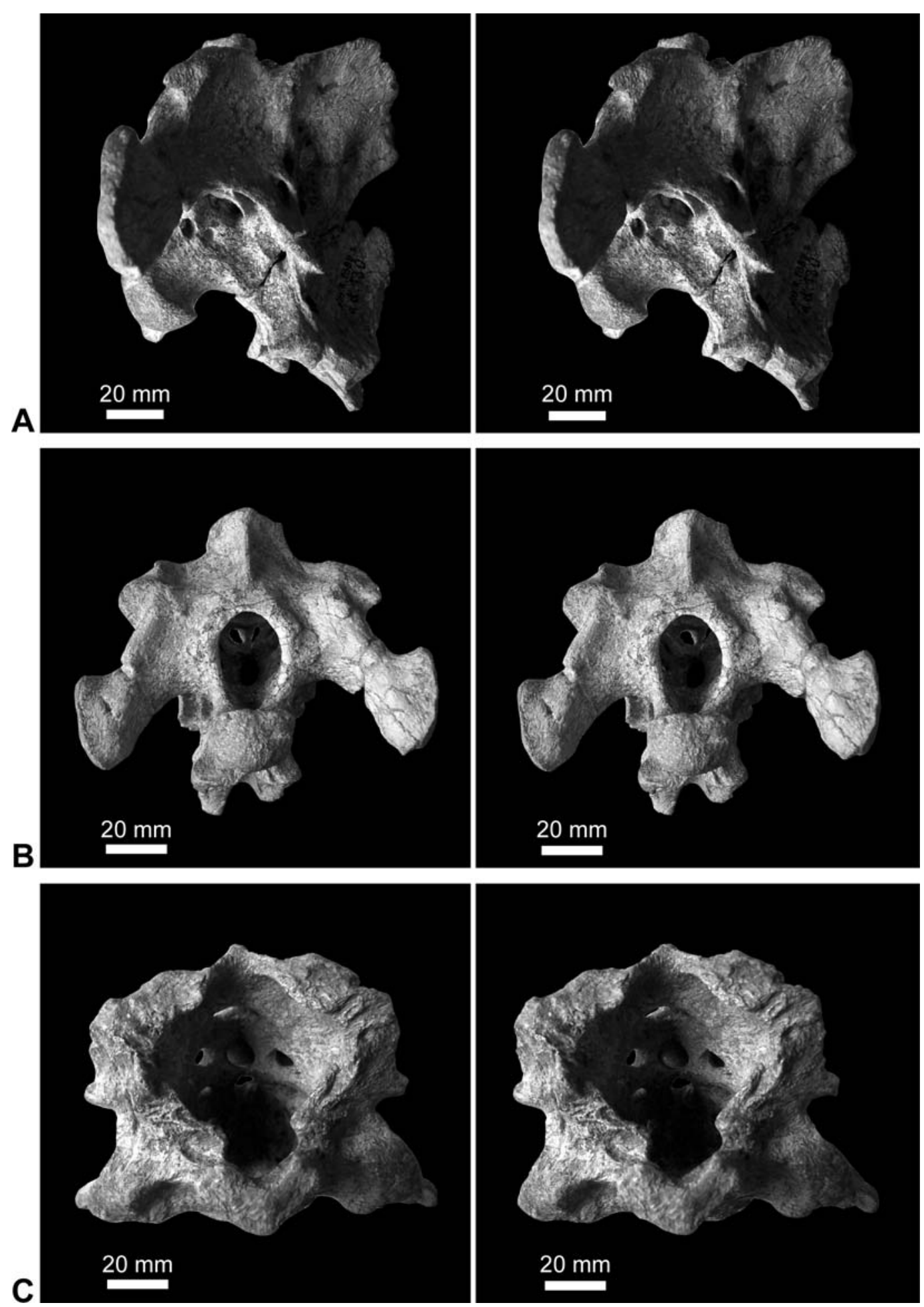

Figure 5. Stereophotographs of braincase MB.R.2388 (dd 130). A. Right lateral view; B. Caudal view; C. Dorsal view. 
church et al. 2004a; Harris 2006c), but recent studies show that this character is more widely distributed and is present at the base of the Flagellicaudata (Harris 2006b). The supraoccipital extends far dorsally beyond the level of the exoccipitals, and bears a strong median crest. There are no elements from the dorsal side of the cranium preserved. On the lateral side of the braincase, the foramina for the cerebral nerves and the prootic and antotic crests are in positions comparable to Tornieria (see Remes 2006). The varying configuration of cranial nerve foramina has not been coded in phylogenetic analyses of Sauropoda yet. Similar to Suuwassea
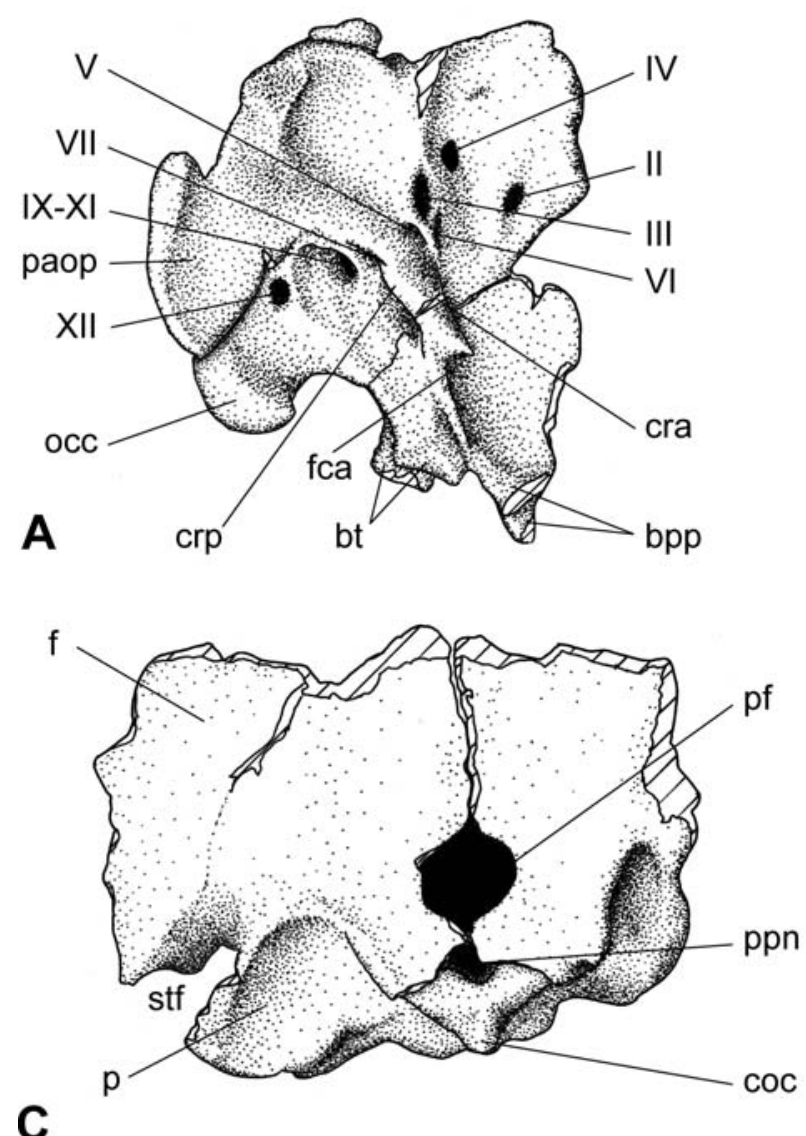
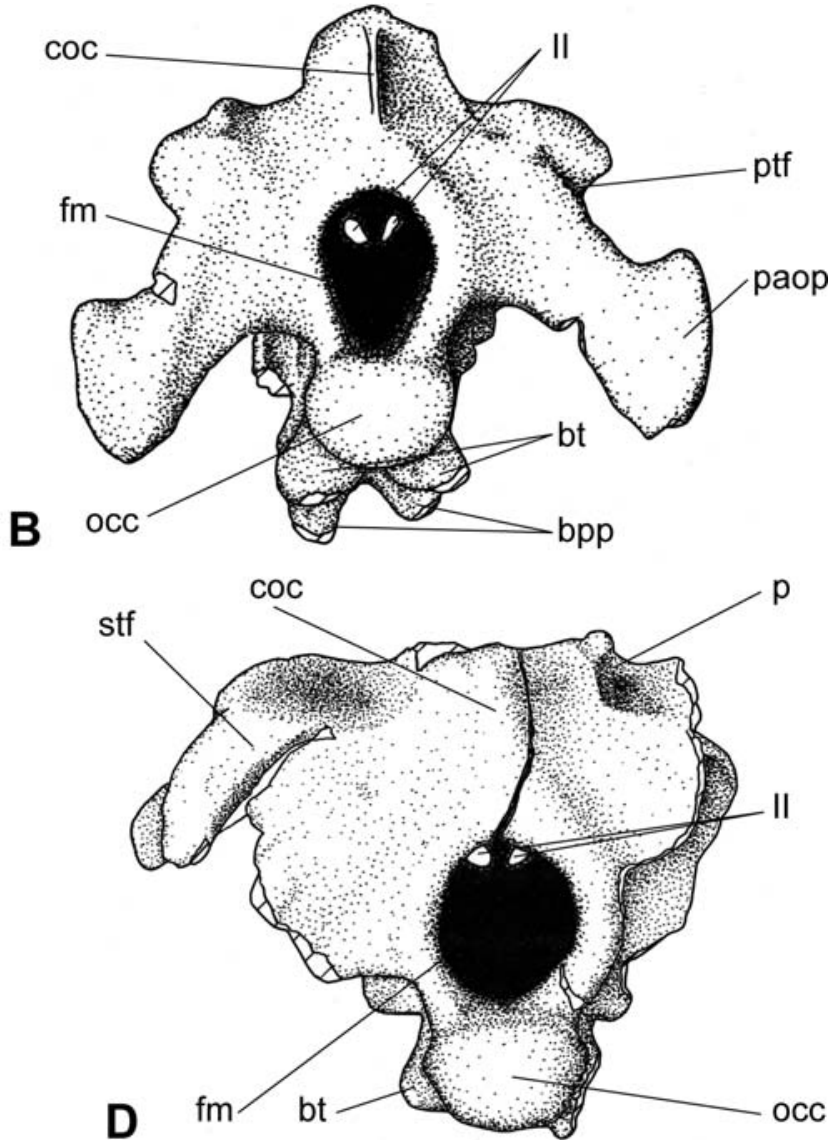

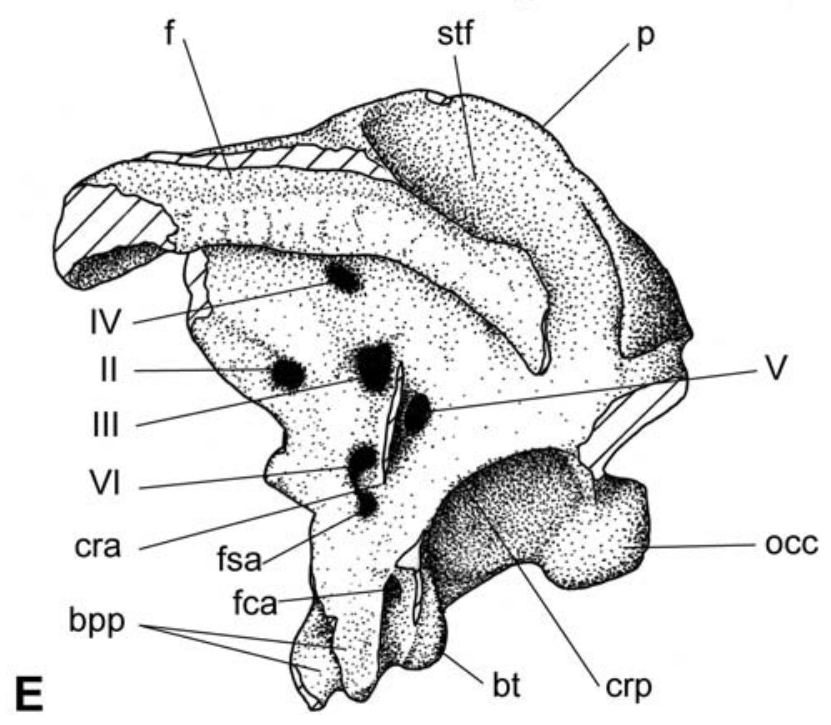

$20 \mathrm{~mm}$

Figure 6. Isolated flagellicaudatan braincases from trench dd, Middle Saurian Beds of the Tendaguru Beds. A. MB.R.2388 (dd 130) in right lateral view; B. Caudal view; C. MB.R.2387 (dd 316) in dorsal view; D. Caudal view; E. Left lateral view. Abbreviations: II-XII - foramina for cranial nerves II-XII; bpp - basipterygoid processes; bt - basal tubera; coc - crista occipitalis; cra - antotic crest; crp - prootic crest; f - frontal; fca - foramen for carotid artery; fm - foramen magnum; fsa - foramen possibly for sphenoid artery; occ - occipital condyle; p - parietal; paof - paroccipital process; pf - parietal foramen; ppn postparietal notch; ptf - posttemporal fenestra; stf - supratemporal fenestra. 
(Harris 2006a), braincase MB.R.2388 (dd 130) and Tornieria both have enlarged foramina for cranial nerves III, IV, and V. The foramen for cranial nerve VI is situated close to the openings for III and V, which differs from dicraeosaurids who have this opening rostroventrally displaced (Janensch 1935-36; Salgado \& Calvo 1992). In MB.R.2388 (dd 130), the antotic crest is much weaker than in Tornieria. Similar to Tornieria (Remes 2006), the basal tubera are suboval in shape, the basipterygoid processes are cylindrical in cross-section, the area between the bases of the basipterygoid processes forms a smooth, rounded shelf, and there is a triangular attachment for the parasphenoid rostrum. The differences to Tornieria, including the smaller size, the form of the occiput, and the weak formation of lateral cristae on the braincase, may be explained by ontogenetic variation (Janensch 1935-36). However, all sutures are completely fused, and based on the dimen-
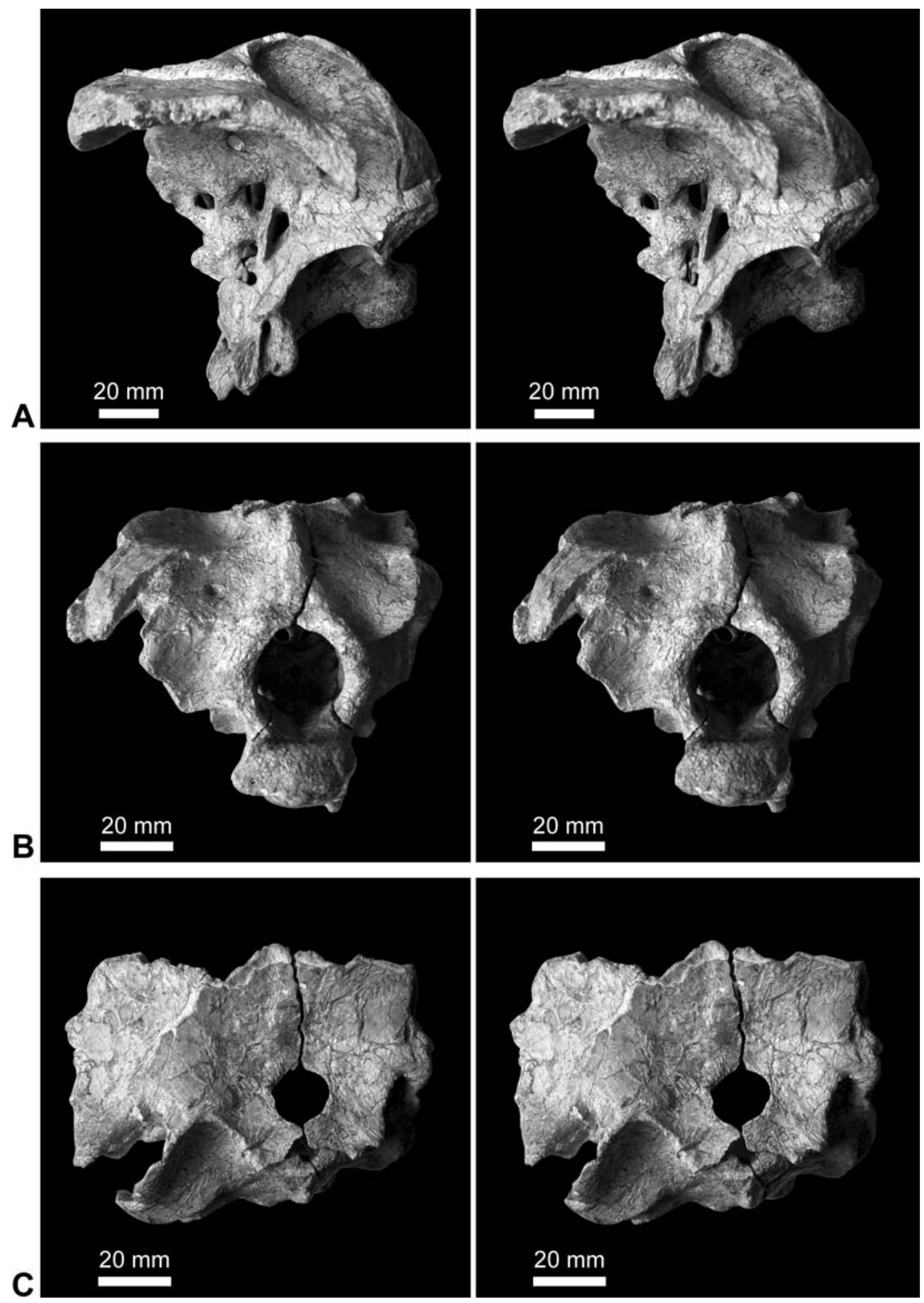

Figure 7. Stereophotographs of braincase MB.R.2387 (dd 316). A. Left lateral view; B. Caudal view; C. Dorsal view. 
sions it can be anticipated that this individual had a skull length of at least $50 \mathrm{~cm}$, only $10 \%$ less than $\mathrm{Di}$ plodocus longus (Holland 1924). Therefore, the individual is expected to have reached sexual maturity already, evoking doubts if morphological variation within a species can reach such a high grade at this point of ontogeny. Consequently, the braincase MB.R.2388 (dd 130) cannot be referred to Tornieria with confidence, and is therefore referred to Flagellicaudata indet. based on the derived characters shared with this group.

\section{Braincase MB.R.2387 (dd 316)}

The braincase MB.R.2387 (dd 316) (Figs 6C-E, 7) is larger than MB.R.2388 (dd 130), but smaller than the known braincase of Tornieria, MB.R.2386 (k 1). It exhibits a number of anatomical differences to both Tornieria and MB.R.2388 (dd 130). Other than in Tornieria, the attachment sites for the neck musculature on the occiput are much more distinct, having the form of deep, oval pits. Like in MB.R.2388 (dd 130), the median crest is more prominently developed than in Tornieria. The foramina for the cranial nerves are comparable in size and positions to Tornieria and MB.R.2388 (dd 130), and are therefore similar to Suuwassea (Harris 2006a) and diplodocids (Berman \& McIntosh 1978). In ventral view, the basal tubera are transversely expanded. The cross-section of the basipterygoid processes is transversely flattened, while it is subcircular in Tornieria and MB.R.2388 (dd 130). Moreover, between the bases of the basipterygoid processes, there is a shallow pit instead of a shelf (approaching the condition seen in dicraeosaurids, which have a deep pit at this position), and there is no clear attachment site for the parasphenoid rostrum rostrally like in MB.R.2388 (dd 130) and Tornieria. Similar to MB.R.2388 (dd 130), the antotic crest is only weakly developed in comparison to Tornieria.

The most marked differences between Tornieria and MB.R.2387 (dd 316) are found on the skull roof. Generally, the bones of the skull roof are unusually thin, thinning to only about $2 \mathrm{~mm}$ strength in some areas. The median suture is completely fused and cannot be observed anymore, and frontals and parietals are likewise fused to each other. Caudally on the median line, there is a $20 \mathrm{~mm}$ wide, circular opening, obviously homologous to the parietal foramen. The bones of the skull roof thin towards the edges of this opening, which bear no fracture surfaces. Hence, this structure is no artifact of preparation. In addition, between the contact of parietal and supraoccipital on the caudodorsal center of the braincase, there is a distinct cleft, the postparietal notch. The rostral part of the skull roof is missing. Laterally, the long axis of the relatively large supratemporal opening is caudolaterally oriented (instead of transversely as in Tornieria), and faces dorsolaterally instead of strictly dorsally, making it visible also in lateral view.
Like in Tornieria and MB.R.2388 (dd 130), the ventrally directed occipital condyle and the rostrolaterally projecting basipterygoid processes allow for identifying MB.R.2388 (dd 130) as a member of Flagellicaudata. Fused frontals, the presence of a parietal foramen, the presence of a postparietal notch, and the lateral orientation of the supratemporal fenestra have been regarded as synapomorphic characters of the Dicraeosauridae (Salgado \& Calvo 1992; Upchurch 1995, 1998; Wilson 2002; Upchurch et al. 2004a; Rauhut et al. 2005; Salgado et al. 2006), but are now known to be presented also in the basal flagellicaudatan Suuwassea (Harris 2006a, 2006c). Other dicraeosaurid characters are missing, including an enlarged dorsolateral process of the prootic crest, parallel, rostrally directed basipterygoid processes, and a reduced transverse width of the basal tubera relative to that of the occipital condyle (Salgado \& Calvo 1992; Upchurch 1998; Wilson 2002; Upchurch et al. 2004a; Rauhut et al. 2005; Salgado et al. 2006). The high number of differences to both Tornieria and MB.R.2388 (dd 130) impedes the referral to the same taxon, and the high number of plesiomorphic characters evokes doubts if this specimen can indeed be referred to Diplodocidae. Instead, it may well represent a new taxon, but the material at hand is too incomplete to erect a new genus. Therefore, braincase MB.R.2388 (dd 130) is referred to Flagellicaudata indet.

\section{Ischium from site $\mathrm{Ki}$}

The digging field at Kijenjere yielded an isolated ischium ( $\mathrm{Ki} \mathrm{14}$ ) that was referred to "Barosaurus africanus" by Janensch (1961). The specimen measures $50 \mathrm{~cm}$ in length and therefore only $60 \%$ of the known ischium of Tornieria (MB.R.2733 [k 44]; Remes 2006). The shaft of the ischium is short and slender. It has a triangular cross-section and an only slightly expanded distal end. Both characters are diagnostic for Flagellicaudata (Upchurch 1998; Wilson 2002; Upchurch et al. 2004a; Rauhut et al. 2005; Harris 2006c; Salgado et al. 2006), but are much more weakly developed than in Tornieria. It cannot be assessed if these differences have ontogenetic reasons or indicate two different taxa; therefore, this specimen is referred to Flagellicaudata indet.

\section{Diplodocoidea Marsh, 1884}

\section{Diplodocoidea indet.}

\section{Atlantal intercentrum from trench $d d$}

The atlantal intercentrum MB.R.2389 (dd ?) was already described by Janensch (1935-36). It was found in trench dd, but did not receive any field number. No taphonomic data about this find exist. The intercentrum is U-shaped in cranial view (contrasting the more rectangular shape of the same element in Dicraeosaurus: 

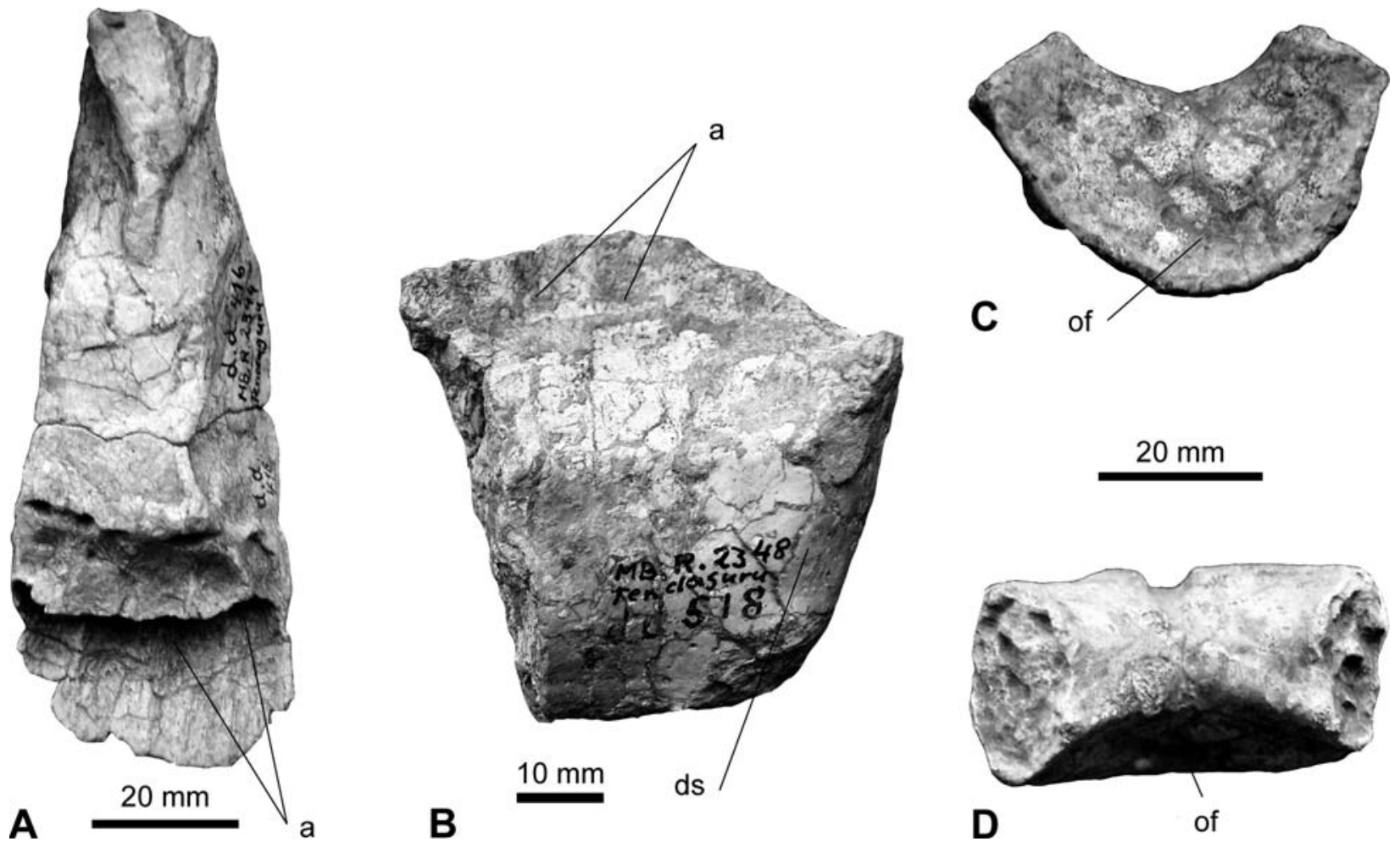

Figure 8. Skull elements of indeterminate sauropods. A. Left premaxilla MB.R.2344 (dd 416) in caudal view; B. Left dentary MB.R.2348 (dd 518) in medial view; C. Atlantal intercentrum MB.R.2389 from trench dd in cranial view; D. Dorsal view. Abbreviations: a - alveoli; ds - dentary symphysis; of - facet for occipital condyle.

Janensch 1929), and has an occipital fossa that is extended in cranioventral direction (Fig. 8C-D). This is a shared derived character of Diplodocoidea (Wilson \& Sereno 1998), allowing to refer this specimen to this group.

\section{Premaxilla MB.R.2344 (dd 416)}

Janensch (1935-36) described an incomplete, isolated left premaxilla MB.R.2344 (dd 416) (Fig. 8A) and referred it to "Barosaurus africanus". The specimen is craniocaudally flattened, dorsoventrally elongate, and lacks the caudal part. Four alveoli are preserved, but contain no teeth. The elongate shape of the premaxilla, and the lack of an offset ventral part are synapomorphic characters of Diplodocoidea (Upchurch 1998; Wilson 2002; Upchurch et al. 2004a; Rauhut et al. 2005; Harris 2006c; Salgado et al. 2006). However, the specimen bears no characters that were diagnostic on family or genus level.

\section{Ilium MB.R.2716 (St 243)}

The small ilium MB.R.2716 (St 243) was found in the Middle Saurian Beds. Beside its dimensions, it differs from the ilium of Tornieria (Remes 2006) in the less prominent development of the preacetabular and postacetabular processes. Like in other Diplodocoidea, the preacetabular process tapers somewhat cranially, and the ischiadic peduncle is strongly reduced in length; both characters are not found in Macronaria (Janensch 1961). Therefore, this specimen may be identified as Diplodocoidea indet., but cannot be referred to any less inclusive taxonomic unit.

\section{Non-diagnostic material (Sauropoda indet.)}

\section{Dentary MB.R.2348 (dd 518)}

Specimen MB.R.2348 (dd 518) is the rostral part of a left dentary (Fig. 8B). It preserves the mandibular symphysis and six alveoli, which are filled with sediment and bear no teeth. There is no indication for a 'chin'like process rostroventrally like in Diplodocus (Holland 1924) or Dicraeosaurus (Janensch 1935-36). However, as compared to Brachiosaurus (Janensch 1935-36), the symphyseal facet is relatively smaller, and the whole element appears less robust. The specimen exhibits no characters that were diagnostic beyond Sauropoda indet.

\section{Isolated bones of the appendicular skeleton}

Humeri. The MB collections still contain 20 humeri labeled "Barosaurus africanus" (Fig. 9), including the two specimens (MB.R.2672 [A 1], MB.R.2673 [k 37]) referred to Tornieria africana (Remes 2006). Only one 


\section{Upper Saurian Beds}

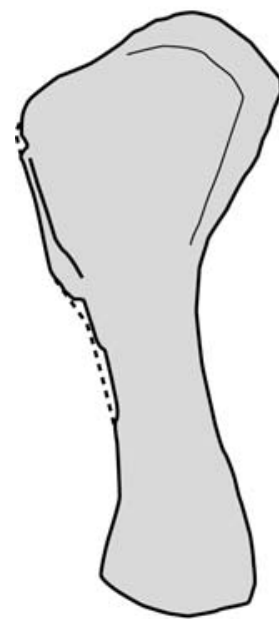

A 1

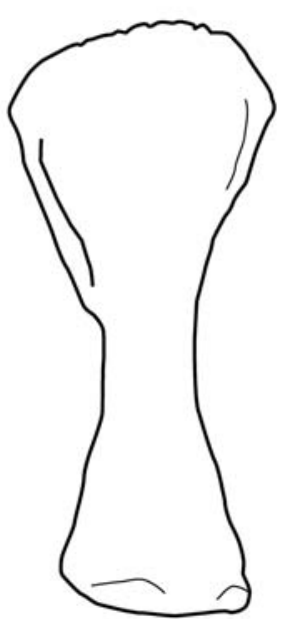

k 37

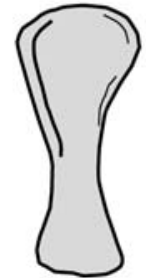

$\mathrm{G}$ ?

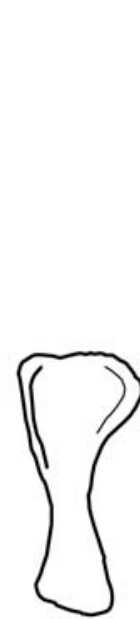

G 81

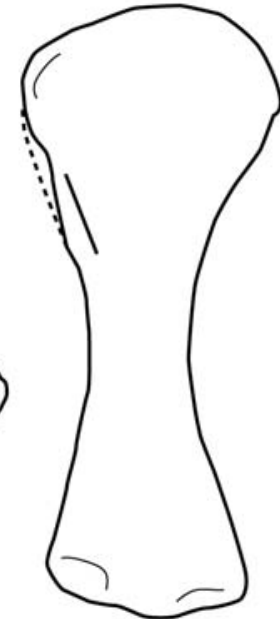

*VIII 1

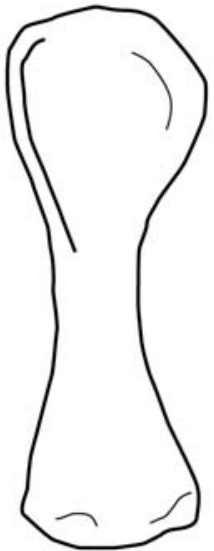

${ }^{*} \mathrm{XV} 8$

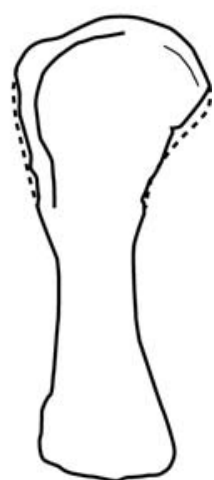

*XV 50

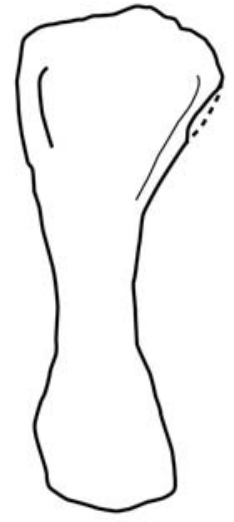

*XV a 17

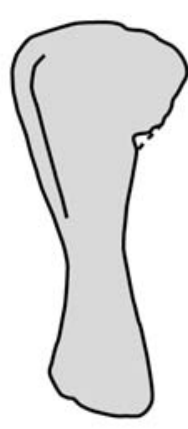

${ }^{*} \mathrm{XV}$ ?

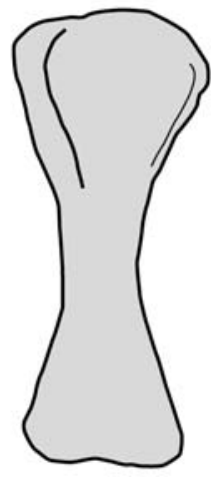

*XVI 64।

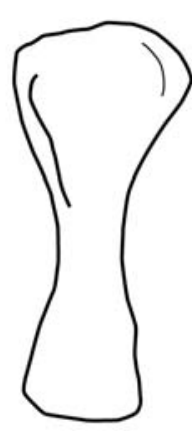

*XVI 66

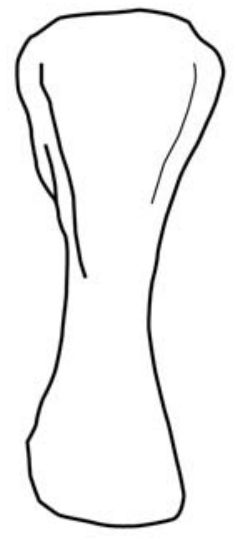

XVI 107 o

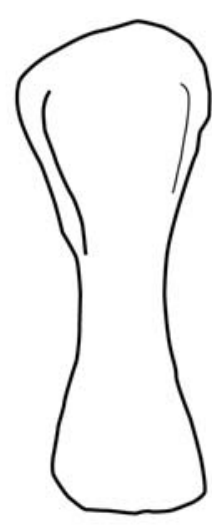

*XVI 128 o

\section{Upper Transitional Sands}

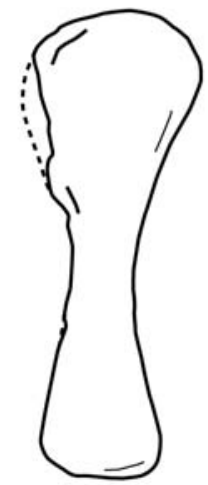

*Ki 3

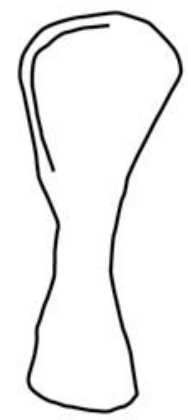

${ }^{*} \mathrm{Ki} 68$ a

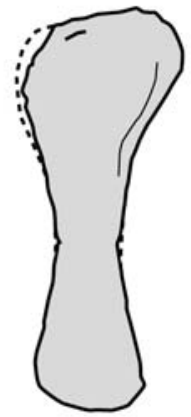

${ }^{*}$ IX 94

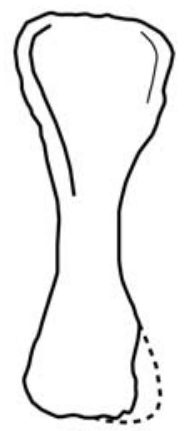

IX k 11

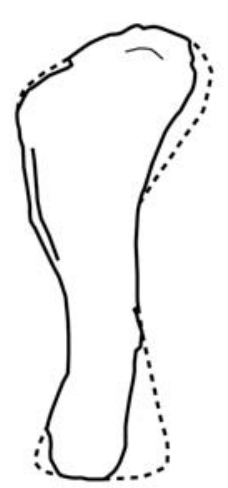

IX 01

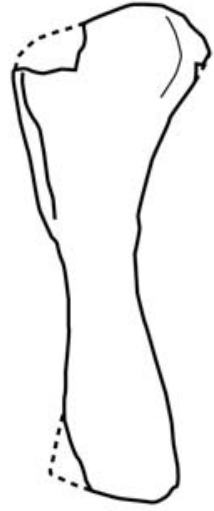

IX t 1

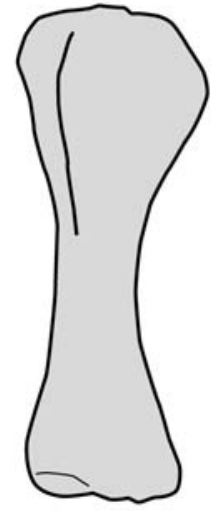

$\mathrm{XI}$ a 7

Figure 9. Comparison of humeri from the Tendaguru Beds originally identified as "Barosaurus africanus", cranial view. Elements attributable to Tornieria africana (Fraas, 1908) (Remes 2006) are marked with bold type. Asterisks indicate elements that were mirrored for better comparison. Hatched lines indicate reconstructed parts of damaged specimens; shaded bones were histologically examined by Sander $(1999,2000)$. 
specimen (MB.R.2646 [VIII 1]) reaches the same size as the Tornieria specimens. The remaining are distinctly smaller, including the particularly small specimens MB.R.2709 (G ?) and MB.R.2656 (G 81), which reach only $43 \%$ of the length of the Tornieria specimens. MB.R.2709 (G ?) and the somewhat larger specimen MB.R.2654 (IX 94) (50\% the length of the Tornieria material) were histologically determined to belong to a juvenile individual (Sander 1999). The humeri differ in the form of their proximal end: Tornieria and most of the isolated humeri have a robust, caudally projecting humeral head and a well-developed caudolateral tubercle. The latter structure is not well developed in other specimens (MB.R.2644 [IX k 11], MB.R.2652 [XV ?], MB.R.2649 [XV 8], MB.R.2651 [XV a 17], MB.R.2648 [XVI 66]) and in Dicraeosaurus (Janensch 1961), while some humeri have a craniocaudally rather slim proximal end and lack a distinct humeral condyle (MB.R.2646 [VIII 1], MB.R.2632 [XVI 107 o], MB.R.2643 [XVI 128 o]). However, it is not clear how strongly diagenetic processes controlled the shape of these specimens. Janensch (1961) noted slightly more slender, less robust proportions in the stratigraphically older specimens from the Upper Transitional Sands. This observation led him to introduce the name "Barosaurus africanus var. gracilis" for these forms, an infrasubspecific term that is not valid according to the rules of zoological nomenclature (ICZN: Kraus 2000; see Remes 2006). Moreover, the spectrum of size and proportions among these specimens is continuous, which is also confirmed by quantitative linear and geometric morphometric analyses (Bonnan 2007), and histological examinations also showed no significant differences (Sander 1999, 2000).

Ulnae. In addition to the ulna of the Tornieria skeleton k (MB.R.2586 [k 38]; Remes 2006), three other ulnae (MB.R.2585 [H 7], MB.R.2602 [Ki 63], MB.R.2604
[Ki 69a]) are labeled "Barosaurus africanus" in the MB collections (Fig. 10A). All specimens come from the Upper Transitional Sands, and are more slender than the ulna of Tornieria. Unlike Tornieria and the Kijenjere specimens, specimen MB.R.2585 (H 7) has an elongate craniomedial process, very much resembling Brachiosaurus (Janensch 1935-36), and may therefore belong to that taxon. However, no diagnostic characters have been described so far for sauropod ulnae, rendering a systematic assignment of these specimens difficult.

Radii. As for the ulnae, only the Upper Transitional Sands yielded radii that were identified as "Barosaurus africanus" by Janensch (1961). These specimens include MB.R.2617 (H 6) and MB.R.2621 (Ki 70a) (Fig. 10B), and cannot be compared to Tornieria since no radius of the latter form is known (Remes 2006). Specimen MB.R.2621 (Ki 70a) was found in articulation with a humerus (MB.R.2639 [Ki 68a]) and the ulna MB.R.2604 (Ki 69a). MB.R.2621 (Ki 70a) is slender and straight, and bears a prominent cranial tubercle immediately distal to the proximal quarter. In contrast, the radius MB.R.2617 (H 6) is curved and transversely flattened, and therefore seems not to belong to the same taxon as the Kijenjere forelimb (although the grades of individual variation within species of dinosaurs are not well known; see also Bonnan et al. 2008). All these elements are not diagnostic beyond Sauropoda indet.

Metacarpals and phalanges. The MB collections label three metacarpals (MB.R.2285 [XV 43], MB.R.2283 [XV 44], MB.R.2282 [IX t 3]) and three manual phalanges (MB.R.2304 [TE a], MB.R.2298 [TL 35], MB.R.2299 [TL 45]), including one ungual (TE a), as belonging to "Barosaurus africanus". It proves difficult to compare these elements to those of other diplodocids, since neither Tornieria nor the North American Barosaurus preserve elements of the manus, and the
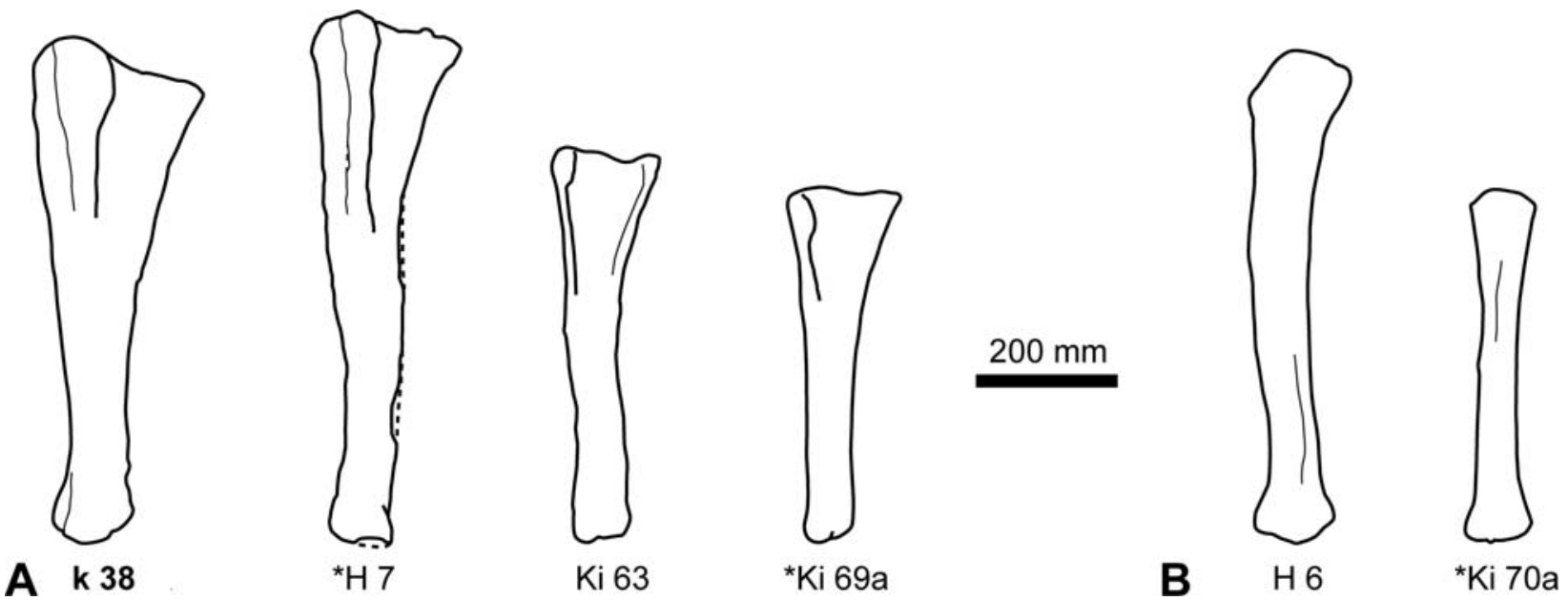

Figure 10. Comparison of antebrachial elements from the Tendaguru Beds originally identified as "Barosaurus africanus". A. Ulnae in right lateral view; B. Radii in cranial view. Elements attributable to Tornieria africana (Remes 2006) are marked with bold type. Asterisks indicate elements that were mirrored for better comparison. Hatched lines indicate reconstructed parts of damaged specimens. 
known metacarpals of Diplodocus carnegii are strongly compressed due to diagenetic processes (Bedell \& Trexler 2005). No characters have been described so far that would distinguish isolated macronarian and diplodocoid metacarpals, with the exception of brachiosaurids, which have a specialized, distinctly elongate metacarpus (Janensch 1961; Bonnan \& Wedel 2004). The phalanges preserved are not as strongly reduced as those of Macronaria, but lack any diagnostic characters that would allow a referral to Diplodocoidea. Therefore, these elements can only be identified as Sauropoda indet.

Pubes. Besides the four pubes listed under Diplodocinae indet. above, two more pubes exist in the MB collections. Specimen H 10 is poorly preserved and therefore does not show characters diagnostic for Diplodocinae, i.e. an enlarged, hook-shaped ambiens process. In specimen e 16, the ambiens process is also broken off. Moreover, the puboischiadic articulation measures about $50 \%$ of the total length of the pubis, compared to about $33 \%$ in the remaining specimens (Fig. 11A). The latter character is usually found in Macronaria only (Salgado et al. 1997; Wilson \& Sereno 1998; Wilson 2002; Upchurch et al. 2004a), and impedes the referral of e 16 to Flagellicaudata. Instead, there are close similarities to the pubis of Janenschia (Janensch 1961: pl. 19, fig. 4).

Femora. Fourteen femora that remain assigned to "Barosaurus africanus" are preserved in the MB collections, including the Tornieria specimen MB.R.2669 (k 40) (Remes 2006). This sample varies primarily in the ratio of total length to minimum width of the shaft (Fig. 11B), which is higher in the specimens from the Upper Transitional Sands as compared to those from the Upper Saurian Beds (Janensch 1961; Russell et al. 1980). However, there are exemptions: MB.R.2667 (H 1) from the Upper Transitional Sands is markedly more robust and differs also in the enlarged great trochanter and the transversely expanded distal end (which may be exaggerated due to compression), while MB.R.2663 (no 1) represents a slender form from the Upper Saurian Beds. In fact, MB.R.2667 (H 1) resembles Brachiosaurus (Janensch 1961) most closely, and may represent a subadult individual of this taxon. As for the humeri, the shape variation of the other specimens appears continuous (as recently confirmed by quantitative morphometric analyses: Bonnan 2007), and there are no differences in the bone histology between the robust specimen MB.R.2670 (NW 4) and the slender femur MB.R.2641 (Ki 71a) (Sander 1999, 2000). However, the medium-sized, slender femora MB.R.2661 (Ki 2) and MB.R.2665 (Ki 4) are deviant in having an exceptionally high number of secondary osteons and LAGs, leading Sander (1999) to suggest sexual dimorphism in "Barosaurus africanus" and to identify these femora as those of a female (since the left femur MB.R.2665 [Ki 4] exactly mirrors the LAG pattern of the right femur MB.R.2661 [Ki 2], it is evident that both specimens come from a single individual; Sander 2000). Given that the taxonomic assignment of these specimens are revised to Sauropoda indet. here, this histological difference actually might reflect phylogenetic disparity (Sander, pers. comm. 2008). Other differences between the individual femora exist in the form of the great trochanter and the lateral shoulder, the relative position of the fourth trochanter, and the shape of the distal articular condyles (Fig. 11B). Although these characters vary among well-known diplodocid taxa like Apatosaurus and Diplodocus (e.g., the fourth trochanter is situated more proximally in $D i$ plodocus: Bonnan 2004, 2007; Wilhite 2005), it is unclear if they are of diagnostic value for sauropods that do not come from strata of the Morrison Formation, especially since these variations are closely tied to limb function (Bonnan 2004, 2007). Moreover, intraspecific variability may also have played a role (see Bonnan et al. 2008).

Tibiae. Twelve tibiae assigned to "Barosaurus africanus" are still present in the MB collections (Fig. 12A), including the Tornieria specimen MB.R.2572 (k 41) and the tibiae from skeletons $\mathrm{C}$ and $\mathrm{K}$ (see above). Six of these come from the Upper Transitional Sands (localities $\mathrm{H}$ and $\mathrm{Ki}$ ) and appear more slender than those from the Upper Saurian Beds, primarily due to a less expanded distal end and a relatively long shaft. Moreover, the size of the cnemial crest and its position relative to the proximal end varies, but it is not known if these characters have diagnostic value or might be due to intraspecific variation. When compared to the North American diplodocines Diplodocus (Hatcher 1901) and Barosaurus (Lull 1919; McIntosh 2005), all tibiae from Tendaguru are more robustly build (see McIntosh 1990a). Sander $(1999,2000)$ showed that specimen MB.R.2596 (Ki 5) has the same unique histology ("Barosaurus type B") as the femur MB.R.2661 (Ki 2) (see above), but he did not sample other tibiae. Therefore, it is currently not possible to test connections between morphological and histological variations. In comparison to other Tendaguru sauropods, all tibiae of the "Barosaurus africanus" sample are more slender than those of $\mathrm{Di}$ craeosaurus (Janensch 1961) or Janenschia (Bonaparte et al. 2000), and lack the incision of the proximal end lateral to the cnemial crest as in Brachiosaurus (Janensch 1961). Therefore, it may be justified to refer these elements to Flagellicaudata indet. or Diplodocidae indet., but since there are no shared derived characters that corroborate such a referral, they are only identified as Sauropoda indet. here.

Fibulae. Eight isolated fibulae in the MB collections are labeled "Barosaurus africanus", but these are all more gracile than that of the Tornieria holotype (SMNS 12142) and lack the prominent medial expansion of the distal end (Fig. 12B). Like in Tornieria (Remes 2006), the triangular muscle attachment on the 


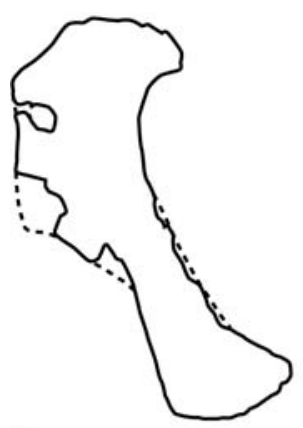

A $\quad$ E 6

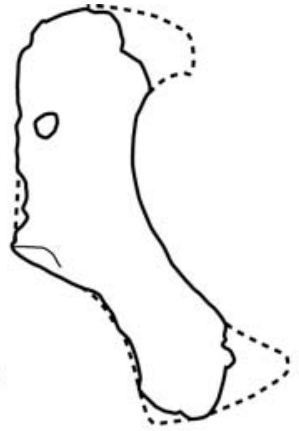

*e 16

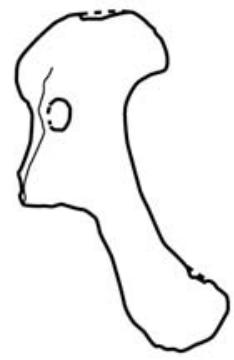

$\mathrm{XI}$ a10

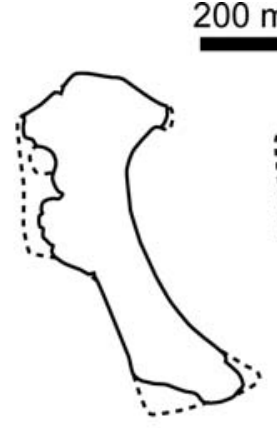

${ }^{*} \mathrm{H} 9$

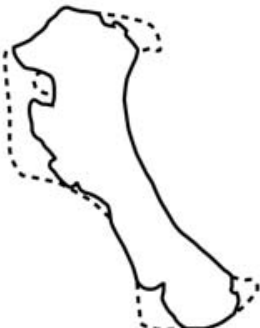

H 10

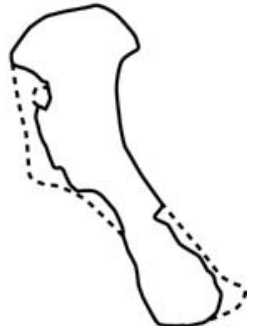

Ki 13

\section{Upper Saurian Beds}

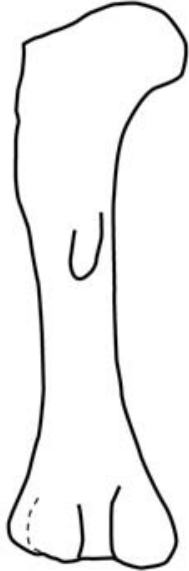

*A

(SMNS 12140)

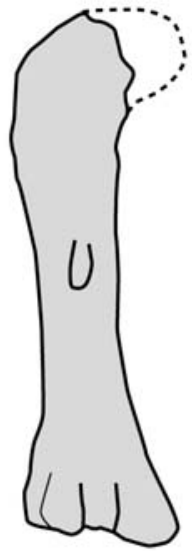

k 40

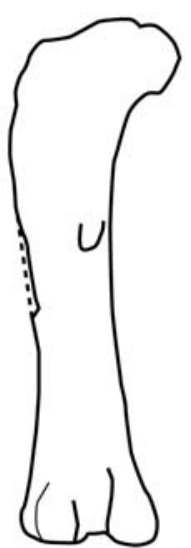

e 2

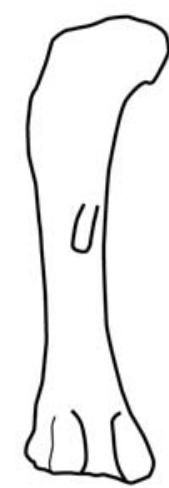

*no 1

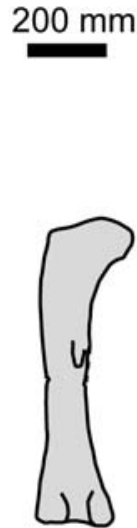

XVII 5

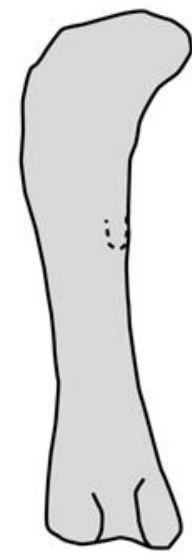

NW 4

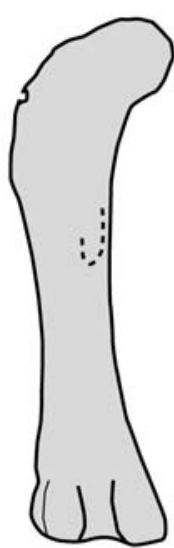

Nr. 76

Upper Transitional Sands

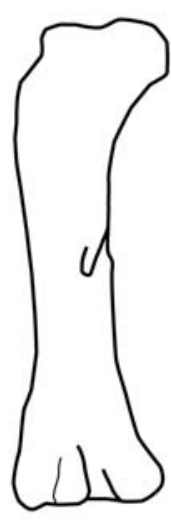

B ${ }^{*} \mathrm{H} 1$

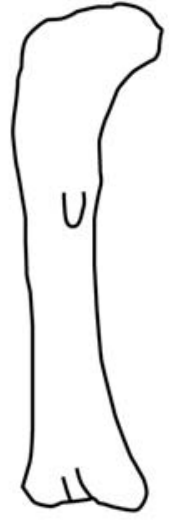

H 4

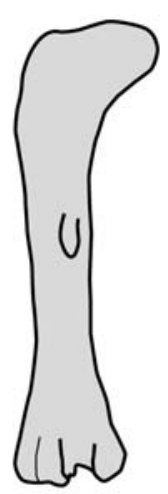

${ }^{*}$ Ki 2

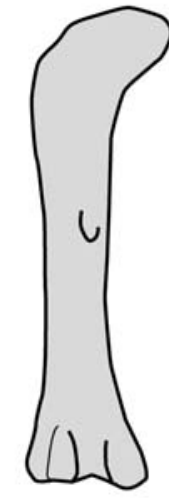

Ki 4
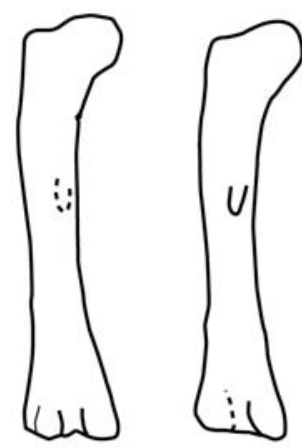

${ }^{*} \mathrm{Ki} 10$
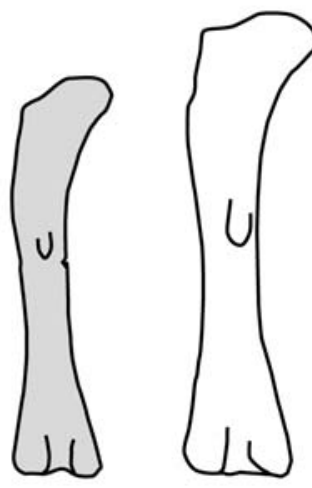

Ki 71a

${ }^{*} \mathrm{IX} 1 \mathrm{a}$

Figure 11. Comparison of pubes and femora from the Tendaguru Beds originally identified as "Barosaurus africanus". A. Pubes in right lateral view; B. Femora in caudal view, showing the position of the fourth trochanter. Elements attributable to Tornieria africana (Remes 2006) are marked with bold type. Asterisks indicate elements that were mirrored for better comparison. Hatched lines indicate reconstructed parts of damaged specimens; shaded bones were histologically examined by Sander (1999, 2000).

proximomedial end is lost in five of these tibiae, while the muscle scar is distinctly developed in MB.R.2612 (H 3), MB.R.2611 (H 5), and MB.R.2619 (NAGD 19). However, the bone histology of fibula MB.R.2611 (H 5) is identical to that of humerus MB.R.2672 (A 1) from the holotype individual of Tornieria ("Barosaurus type A"; Sander 1999, 2000). Hence, it may be possible that there was either a great amount of morphological variation within Tornieria (see also Bonnan et al. 2008), or that another Tendaguru sauropod species had 
identical histological characters. Since this issue currently cannot be resolved, all these fibulae have to be addressed as Sauropoda indet. only.

Astragalus. Wilson (2002) lists the reduction of foramina on the tibial articular facet of the astragalus as autapomorphic for Apatosaurus. None of the seven astragalus formerly referred to "Barosaurus africanus" shows this character, including that of the Tornieria holotype SMNS 12145b (Remes 2006) and the two specimens from skeleton $\mathrm{K}$ described above (Fig. 12C). All astra- galus have an ascending process that extends to the caudal border of the element, a shared derived character of higher eusauropods (Wilson 2002; Bonnan 2005). However, there are major differences in size, length-towidth ratios, and general shape. For example, the astragalus found in association with the Tornieria holotype and the isolated pes MB.R.2370 (Nr. 28) have a trapezoidal shape like in Apatosaurus (Bonnan 2005: fig. 16.2), while the two astragalus from skeleton $\mathrm{K}$ are subtriangular with a pointed medial end, like in $D i$ craeosaurus hansemanni (Janensch 1961: fig. 23). The

\section{Upper Saurian Beds}
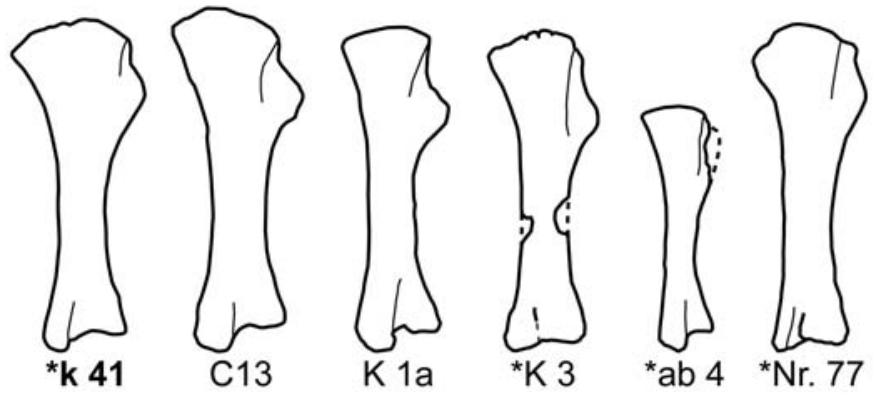

Upper Transitional Sands

A
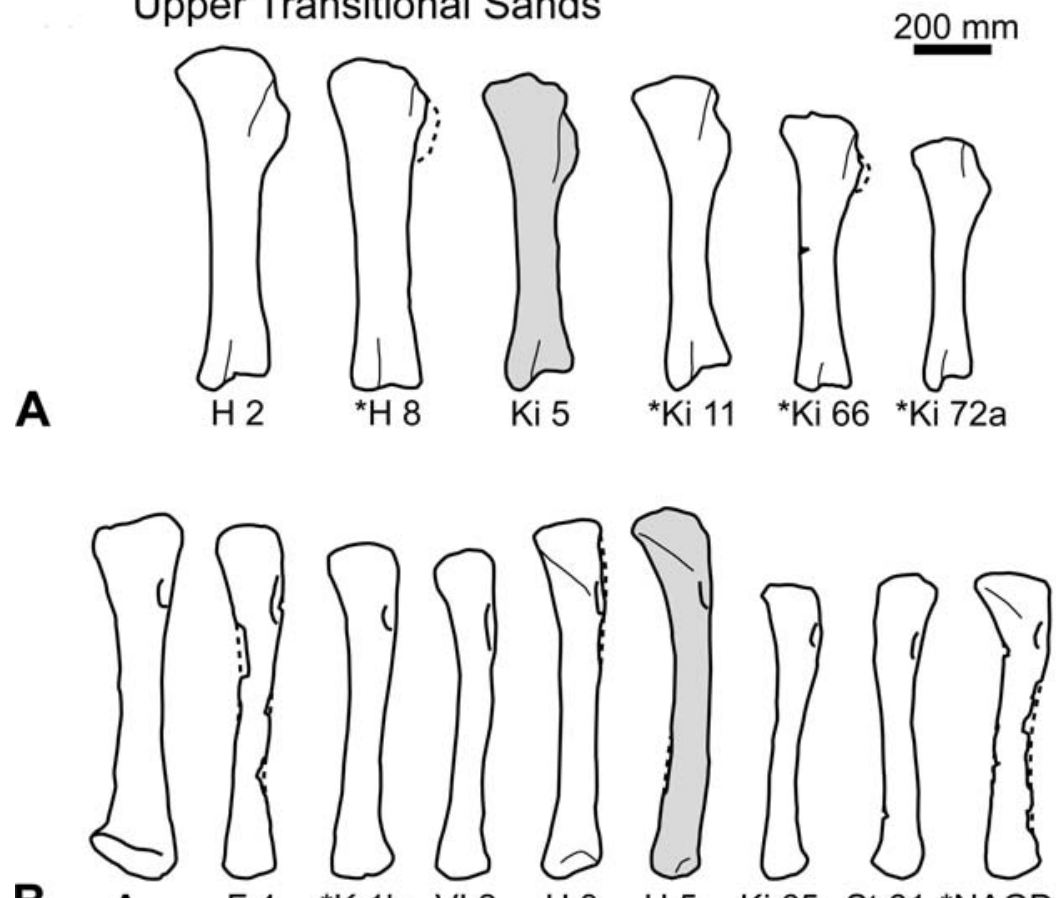

(SMNS 12142)

$\mathrm{H} 3$

$\mathrm{H} 5$

Ki 65

St 61 *NAGD 19

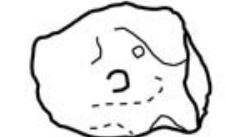

A (SMNS 12145b)
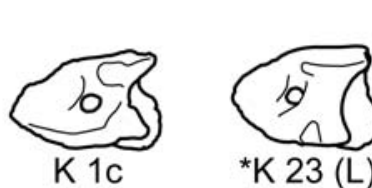

$100 \mathrm{~mm}$
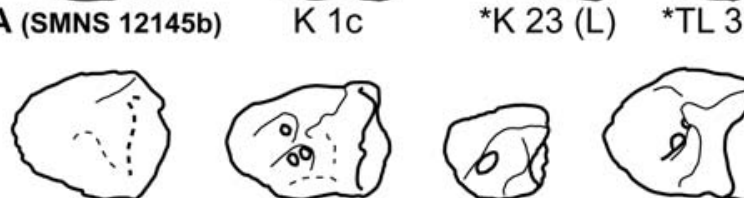

C ${ }^{*} \mathrm{Nr} .28$

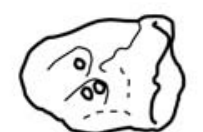

${ }^{\star} \mathrm{Nr} .79$

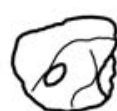

Ob 5

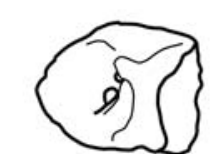

*MB.R.2567
Figure 12. Comparison of distal hind limb elements from the Tendaguru Beds originally identified as "Barosaurus africanus". A. Tibiae in left lateral view; B. Fibulae in medial view; C. Astragalus in proximal view. Elements attributable to Tornieria africana (Remes 2006) are marked with bold type. Asterisks indicate elements that were mirrored for better comparison. Hatched lines indicate reconstructed parts of damaged specimens; shaded bones were histologically examined by Sander $(1999,2000)$. 
shape variation in the "Barosaurus africanus" astragalus sample is large, and no characters diagnostic on genus level could be defined for this element. Although there is a general resemblance to other diplodocid astragalus (see Bonnan 2005), these elements currently can only be identified as coming from indeterminate eusauropods.

Pedal elements. In addition to the articulated feet MB.R.2370 (Nr. 28) and MB.R.2371 (XIII 10), and the two isolated first metatarsals MB.R.2400 (XVI 21) and MB.R.2286 (XVI 28) described above, six isolated metatarsals and six pedal phalanges are labeled as "Barosaurus africanus" in the MB collections (see Appendix). None of these exhibits characters that are diagnostic on a less inclusive taxonomic level than Sauropoda indet.

\section{Discussion}

This review of a large sample of sauropod remains demonstrates that our understanding of the Tendaguru fauna is still incomplete, and that further investigations and discoveries are necessary to come to a better assessment of intraspecific variability of sauropods. The lack of detailed knowledge about the anatomical characters and grade of variation in sauropod limb elements still hampers the identification of isolated elements. Although morphological variation is apparent, it cannot be assessed how many different species are represented in the Tendaguru sample. This would make necessary a detailed examination of minor anatomical differences in the limbs of all sauropods, which is beyond the scope of this study. Nevertheless, the grade of variation observed supports the observation that there are at least two different representatives of the Diplodocidae (Remes 2007). This mirrors the contemporaneous Morrison Formation of North America, where diplodocids with medium-elongated necks coexisted with closely related taxa that had strongly elongated necks (see Foster 2003). However, it is impossible to refer these elements to Tornieria africana, Australodocus bohetii, or a new taxon.

The most conspicuous specimens among this sample are the isolated braincases MB.R.2388 (dd 130) and MB.R.2387 (dd 316), skeleton H, and the hind limb elements of skeleton $\mathrm{K}$. The braincases from trench dd illustrate our lack of knowledge about sauropod skull anatomy, ontogeny, and variability most clearly. The differences between these specimens and the braincase of Tornieria africana are significant, and may in part be explained by the temporal gap of 2 to 5 million years between the Upper and Middle Saurian Beds (Table 1). However, the characters of MB.R.2387 (dd 316) are unlike those of all known diplodocid skulls, and may indicate that aside from Dicraeosaurus, Tornieria, and Australodocus, another basal flagellicaudatan similar to Suuwassea inhabited the Tendaguru ecosystem.
Only new discoveries of more complete, better preserved specimens can solve this issue.

The elements from site $\mathrm{H}$, the individual unity of which has already been doubted (Heinrich 1999), also vary in their anatomical characters and therefore do not belong to the same taxon. Instead, the elements seem to represent a diplodocine (pubis H 9), potentially a subadult brachiosaurid (ulna MB.R.2585 [H 7], possibly radius MB.R.2617 [H 6], femur MB.R.2667 [H 1]), and indeterminate elements that may belong to the diplodocine or another form (pubis H 10, femur MB.R.2685 [H 4], tibiae MB.R.2578 [H 2] and MB.R.2579 [H 8], fibulae MB.R.2612 [H 3] and MB.R.2611 [H 5]). Since all these elements are deviant in shape from Tornieria, it may be that at least some of them belong to Australodocus, but since there is no overlap with the holotype of the latter taxon, this cannot be tested.

The hind limb elements of skeleton $\mathrm{K}$ are deviant from the type and referred material of Tornieria africa$n a$, but also show a number of anatomical differences to the elements from site H. Therefore, both sites appear to have preserved different taxa, again indicating that, in addition to Tornieria, Australodocus, and Dicraeosaurus, more flagellicaudatans (probably diplodocids) may have been present in the Tendaguru faunal association. The association of the hind limb elements of skeleton $\mathrm{K}$ with caudal vertebrae that exhibit characters diagnostic for Tornieria (position of the pleurocoels, shape of the ventral longitudinal hollow; Remes 2006) might indicate that these characters have a wider distribution, or that site $\mathrm{K}$ is actually a multi-taxon assemblage.

In most cases, the Tendaguru finds cannot be interpreted further because of the loss of taphonomic data, rendering these bones a collection of isolated elements that might belong to two or more different species. This lack of understanding points to the necessity of further discoveries in the future, in order to get more conclusive data about the anatomy and variation of the Tendaguru sauropods. Nevertheless, the taxonomic uncertainties about the "Barosaurus africanus" material described in this contribution have to be kept in mind for forthcoming studies, to avoid incorrect conclusion based on a false assumption of taxonomic unity.

\section{Acknowledgements}

I am grateful to Oliver Rauhut, who proposed this project, and Thomas Martin for their supervision and support. I also thank all those who helped me with logistics, information exchange, and access to specimens, including Wolf-Dieter Heinrich, David M. Unwin, HansPeter Schultze, Andreas Jahn, Jerry D. Harris, Angela Milner, and Jeffrey A. Wilson. My gratitude goes to editor Dieter Korn and reviewers Matt Bonnan and Leonardo Salgado, who made constructive suggestions to improve an earlier draft of the manuscript. This is contribution number 45 to the DFG Research Unit 533 "Biology of the Sauropod Dinosaurs". 


\section{References}

Aberhan, M., Bussert, R., Heinrich, W.-D., Schrank, E., Schultka, S., Sames, B., Kriwet, J. \& Kapilima, S. 2002. Palaeoecology and depositional environments of the Tendaguru Beds (Late Jurassic to Early Cretaceous, Tanzania). - Mitteilungen aus dem Museum für Naturkunde in Berlin, Geowissenschaftliche Reihe 5: 19-44.

Bedell, M. W. \& Trexler, D. L. 2005. First articulated manus of Diplodocus carnegii. In Tidwell, V. \& Carpenter, K. (eds). Thunder-Lizards: The Sauropodomorph Dinosaurs. Indiana University Press, Bloomington: pp. 302-320.

Berman, D. S. \& McIntosh, J. S. 1978. Skull and relationships of the Upper Jurassic sauropod Apatosaurus (Reptilia, Saurischia). Bulletin of the Carnegie Museum of Natural History 8: 1-35.

Bonaparte, J. F., Heinrich, W.-D. \& Wild, R. 2000. Review of Janenschia Wild, with the description of a new sauropod from the Tendaguru beds of Tanzania and a discussion on the systematic value of procoelus caudal vertebra in the Sauropoda. - Palaeontographica A 256: 25-76.

Bonnan, M. F. 2000. The presence of a calcaneum in a diplodocid sauropod. - Journal of Vertebrate Paleontology 20 (2): 317-323.

Bonnan, M. F. 2004. Morphometric analysis of humerus and femur shape in Morrison sauropods: implications for functional morphology and paleobiology. - Paleobiology 30 (3): 444-470.

Bonnan, M. F. 2005. Pes anatomy in sauropod dinosaurs: implications for functional morphology, evolution, and phylogeny. In Tidwell, V. \& Carpenter, K. (eds). Thunder-Lizards: The Sauropodomorph Dinosaurs. Indiana University Press, Bloomington: pp. 346-380.

Bonnan, M. F. 2007. Linear and geometric morphometric analysis of long bone scaling patterns in Jurassic neosauropod dinosaurs: Their functional and paleobiological implications. - Anatomical Record 290: 1089-1111.

Bonnan, M. F. \& Wedel, M. J. 2004. The first occurrence of Brachiosaurus (Dinosauria: Sauropoda) from the Upper Jurassic Morrison Formation of Oklahoma. - PaleoBios 24 (2): 13-21.

Bonnan, M. F., Farlow, J. O. \& Masters, S. 2008. Using linear and geometric morphometrics to detect intraspecific variability and sexual dimorphism in femoral shape in Alligator mississippiensis and its implications for sexing fossil archosaurs. - Journal of Vertebrate Paleontology 28 (2): 422-431.

Calvo, J. O. \& Salgado, L. 1995. Rebbachisaurus tessonei sp. nov. a new Sauropoda from the Albain-Cenomanian of Argentina; new evidence on the origin of the Diplodocidae. - GAIA 11: 13-33.

Carvalho, I. D. S., Avilla, L. d. S. \& Salgado, L. 2003. Amazonsaurus maranhensis gen. et sp. nov. (Sauropoda, Diplodocoidea) from the Lower Cretaceous (Aptian-Albian) of Brazil. - Cretaceous Research 24: 697-713.

Foster, J. R. 2003. Paleoecological Analysis of the Vertebrate Fauna of the Morrison Formation (Upper Jurassic), Rocky Mountain Region, U.S.A. - New Mexico Museum of Natural History and Science Bulletin 23: 1-95.

Fraas, E. 1908. Ostafrikanische Dinosaurier. - Palaeontographica 55: $105-144$.

Gilmore, C. W. 1936. Osteology of Apatosaurus, with special reference to specimens in the Carnegie Museum. - Memoirs of the Carnegie Museum 11: 175-271.

Harris, J. D. 2006a. Cranial osteology of Suuwassea emilieae (Sauropoda: Diplodocoidea: Flagellicaudata) from the Upper Jurassic Morrison Formation of Montana, USA. - Journal of Vertebrate Paleontology 26 (1): 88-102.

Harris, J. D. 2006b. The axial skeleton of the dinosaur Suuwassea emilieae (Sauropoda: Flagellicaudata) from the Upper Jurassic Morrison Formation of Montana, USA. - Palaeontology 49 (5): $1091-1122$

Harris, J. D. 2006c. The significance of Suuwassea emiliae (Dinosauria: Sauropoda) for flagellicaudatan intrarelationships and evolution. - Journal of Systematic Palaeontology 4: 185-198.
Harris, J. D. 2007. The appendicular skeleton of Suuwassea emilieae (Sauropoda: Flagellicaudata) from the Upper Jurassic Morrison Formation of Montana (USA). - Geobios 40 (4): $501-522$.

Harris, J. D. \& Dodson, P. 2004. A new diplodocoid sauropod dinosaur from the Upper Jurassic Morrison Formation of Montana, USA. - Acta Palaeontologica Polonica 49 (2): 197-210.

Hatcher, J. B. 1901. Diplodocus (Marsh): its osteology, taxonomy, and probable habits, with a restoration of the skeleton. - Memoirs of the Carnegie Museum 1: 1-63.

Heinrich, W.-D. 1999. The taphonomy of dinosaurs from the Upper Jurassic of Tendaguru (Tanzania) based on field sketches of the German Tendaguru Expedition (1909-1913). - Mitteilungen aus dem Museum für Naturkunde in Berlin, Geowissenschaftliche Reihe 2: $25-61$.

Hennig, E. 1915. Kentrosaurus aethiopicus, der Stegosauride des Tendaguru. - Sitzungsberichte der Gesellschaft Naturforschender Freunde zu Berlin 1915: 219-247.

Holland, W. J. 1924. The skull of Diplodocus. - Memoirs of the Carnegie Museum 9: 379-403.

Huene, F. v. 1932. Die fossile Reptil-Ordnung Saurischia, ihre Entwicklung und Geschichte. - Monographien zur Geologie und Palaeontologie (Serie 1) 4: 1-361.

Janensch, W. 1914a. Übersicht über die Wirbeltierfauna der Tendaguruschichten, nebst einer kurzen Charakterisierung der neu aufgeführten Arten von Sauropoden. - Archiv für Biontologie 3 (1) $81-110$.

Janensch, W. 1914b. Die Gliederung der Tendaguru-Schichten im Tendaguru-Gebiet und die Entstehung der Saurier-Lagerstätten. - Archiv für Biontologie 3 (3): 227-261.

Janensch, W. 1920. Über Elaphrosaurus bambergi und die Megalosaurier aus den Tendaguru-Schichten Deutsch-Ostafrikas. - Sitzungsberichte der Gesellschaft Naturforschender Freunde zu Berlin 1920: 225-235

Janensch, W. 1922. Das Handskelett von Gigantosaurus robustus und Brachiosaurus brancai aus den Tendaguru-Schichten Deutsch-Ostafrikas. - Centralblatt für Mineralogie, Geologie und Paläontologie 1922: 464-480.

Janensch, W. 1925a. Die Grabungsstellen der Tendaguru-Gegend. Palaeontographica Supplement 7 (1): XVII-XIX.

Janensch, W. 1925b. Die Coelurosaurier und Theropoden der Tendaguru-Schichten Deutsch-Ostafrikas. - Palaeontographica Supplement 7 (1): 1-99.

Janensch, W. 1929. Material und Formengehalt der Sauropoden in der Ausbeute der Tendaguru-Expedition. - Palaeontographica Supplement 7 (2): 3-34.

Janensch, W. 1935-36. Die Schädel der Sauropoden Brachiosaurus, Barosaurus und Dicraeosaurus aus den Tendaguru-Schichten Deutsch-Ostafrikas. - Palaeontographica Supplement 7 (2): 147 298.

Janensch, W. 1961. Die Gliedmaßen und Gliedmaßengürtel der Sauropoden der Tendaguru-Schichten. - Palaeontographica Supplement 7 (3): 177-235.

Jensen, J. A. 1985. Three new sauropod dinosaurs from the Upper Jurassic of Colorado. - Great Basin Naturalist 45: 697-709.

Kraus, O. 2000. Internationale Regeln für die Zoologische Nomenklatur, vierte Auflage. Offizieller deutscher Text. Goecke \& Evers, Keltern-Weiler.

Lovelace, D. M., Hartman, S. A. \& Wahl, W. R. 2007. Morphology of a specimen of Supersaurus (Dinosauria, Sauropoda) from the Morrison Formation of Wyoming, and a re-evaluation of diplodocid phylogeny. - Arquivos do Museu Nacional Rio de Janeiro 65 (4): 527-544.

Lull, R. S. 1919. The sauropod dinosaur Barosaurus Marsh. - Memoirs of the Connecticut Academy of Arts and Sciences 6: 1-42.

Maier, G. 2003. African Dinosaurs Unearthed. The Tendaguru Expeditions. Indiana University Press, Bloomington. 
Marsh, O. C. 1877. Notice of new dinosaurian reptiles from the Jurassic Formation. - American Journal of Science (Series 3) 14: $514-516$

Marsh, O. C. 1878. Principal characters of American Jurassic dinosaurs. Part I. - American Journal of Science (Series 3) 16: 411416.

Marsh, O. C. 1884. Principal characters of American Jurassic dinosaurs. Part VII. On the Diplodocidae, a new family of the Sauropoda. - American Journal of Science (Series 3) 27: 161-167.

Marsh, O. C. 1890. Description of new dinosaurian reptiles. - American Journal of Science (Series 3) 39: 81-86.

Marsh, O. C. 1895. On the affinities and classification of dinosaurian reptiles. - American Journal of Science (Series 3) 50: 483-498.

McIntosh, J. S. 1990a. Species determination in sauropod dinosaurs with tentative suggestions for their classification. In Carpenter, $\mathrm{K}$. \& Currie, P. J. (eds). Dinosaur systematics - Approaches and perspectives. Cambridge University Press, Cambridge: pp. 53-69.

McIntosh, J. S. 1990b. Sauropoda. In Weishampel, D. B., Dodson, P. \& Osmólska, H. (eds). The Dinosauria. University of California Press, Berkeley: pp. 345-401.

McIntosh, J. S. 2005. The genus Barosaurus Marsh (Sauropoda, Diplodocidae). In Tidwell, V. \& Carpenter, K. (eds). Thunder-Lizards. The Sauropodomorph Dinosaurs. Indiana University Press, Bloomington: pp. 38-77.

Rauhut, O. W. M., Remes, K., Fechner, R., Cladera, G. \& Puerta, P. 2005. Discovery of a short-necked sauropod dinosaur from the Late Jurassic of Patagonia. - Nature 435: 670-672.

Remes, K. 2004. Der Tendaguru-Sauropode "Barosaurus" africanus und die Paläobiogeographie der Diplodocidae (Sauropoda). In Reitner, J., Reich, M. \& Schmidt, G. (eds). Geobiologie. 74. Jahrestagung der Paläontologischen Gesellschaft, Göttingen, 02. bis 08 . Oktober 2004. Kurzfassungen der Vorträge und Poster. Universitätsverlag Göttingen, Göttingen: pp. 195-196.

Remes, K. 2006. Revision of the Tendaguru sauropod Tornieria africana (Fraas) and its relevance for sauropod paleobiogeography. Journal of Vertebrate Paleontology 26 (3): 651-669.

Remes, K. 2007. A second Gondwanan diplodocid dinosaur (Sauropo$\mathrm{da}$, Diplodocoidea) from the Upper Jurassic Tendaguru Beds of Tanzania, East Africa. - Palaeontology 50 (3): 653-667.

Russell, D. A., Béland, P. \& McIntosh, J. S. 1980. Paleoecology of the dinosaurs of Tendaguru (Tanzania). - Memoires de la Société géologique de la France, Nouvelle Série 139: 169-175.

Salgado, L. \& Calvo, J. O. 1992. Cranial osteology of Amargasaurus cazaui Salgado \& Bonaparte (Sauropoda, Dicraeosauridae) from the Neocomian of Patagonia. - Ameghiniana 29: 337-346.
Salgado, L., Coria, R. A. \& Calvo, J. O. 1997. Evolution of titanosaurid sauropods. I: phylogenetic analysis based on the postcranial evidence. - Ameghiniana 34 (1): 3-32.

Salgado, L., Garrido, A., Cocca, S. E. \& Cocca, J. R. 2004. Lower Cretaceous rebbachisaurid sauropods from Cerro Aguada del León (Lohan Cura Formation), Neuquén Province, northwestern Patagonia, Argentina. - Journal of Vertebrate Paleontology 24 (4): 903-912.

Salgado, L., Carvalho, I. D. S. \& Garrido, A. C. 2006. Zapalasaurus bonapartei, a new sauropod dinosaur from La Amarga Formation (Lower Cretaceous), northwestern Patagonia, Neuquén Province, Argentina. - Geobios 39: 695-707.

Sander, P. M. 1999. Life history of Tendaguru sauropods as inferred from long bone histology. - Mitteilungen aus dem Museum für Naturkunde in Berlin, Geowissenschaftliche Reihe 2: 103-112.

Sander, P. M. 2000. Long bone histology of the Tendaguru sauropods: Implications for growth and biology. - Paleobiology 26 (3): 466488.

Seeley, H. G. 1888. The classification of the Dinosauria. - Report of the British Association for the Advancement of Science 1887: 698-699.

Upchurch, P. 1995. The evolutionary history of sauropod dinosaurs. Philosophical Transactions, Royal Society of London, B 349 (1330): 365-390.

Upchurch, P. 1998. The phylogenetic relationships of sauropod dinosaurs. - Zoological Journal of the Linnean Society 124: 43-103.

Upchurch, P., Barrett, P. M. \& Dodson, P. 2004a. Sauropoda. In Weishampel, D. B., Dodson, P. \& Osmolska, H. (eds). The Dinosauria (2nd edition). University of California Press, Berkeley: pp. 259-322.

Upchurch, P., Tomida, Y. \& Barrett, P. M. 2004b. A new specimen of Apatosaurus ajax (Sauropoda: Diplodocidae) from the Morrison Formation (Upper Jurassic) of Wyoming, USA. - National Science Museum Monographs 26: 1-108.

Wilhite, D. R. 2005. Variation in the appendicular skeleton of North American sauropod dinosaurs: taxonomic implications. In Tidwell, V. \& Carpenter, K. (eds). Thunder-Lizards: The Sauropodomorph Dinosaurs. Indiana University Press, Bloomington: pp. 268-301.

Wilson, J. A. \& Sereno, P. C. 1998. Early evolution and higher-level phylogeny of sauropod dinosaurs. - Journal of Vertebrate Paleontology Memoir 5: 1-68.

Wilson, J. A. 2002. Sauropod dinosaur phylogeny: critique and cladistic analysis. - Zoological Journal of the Linnean Society 136: 217-276. 


\section{Appendix}

List of specimens in the MB collections originally referred to "Barosaurus africanus" (Fraas, 1908), excluding Tornieria africana (Fraas, 1908) (see Remes 2006) and Australodocus bohetii Remes, 2007 (see Remes 2007). Specimens are sorted stratigraphically and by excavation sites.

\begin{tabular}{|c|c|c|c|c|}
\hline Specimen & Catalogue no. & FN & References & Comments \\
\hline \multicolumn{5}{|l|}{ Upper Saurian Beds: } \\
\hline Left tibia & MB.R.2580 & ab 4 & Heinrich (1999: 40; fig. 9) & \\
\hline Right tibia & MB.R.2592 & C 13 & Heinrich (1999: 33; fig. 2) & \\
\hline Right pubis & MB.R.2736 & E 6 & $\begin{array}{l}\text { Janensch (1961: 202; tab. 10; } \\
\text { pl. 19, fig. 1) }\end{array}$ & \\
\hline Left pubis & - & e 16 & & $\begin{array}{l}\text { Janensch (1929) mentions the } \\
\text { existence of a pubis from site e, } \\
\text { but gives no field number }\end{array}$ \\
\hline Left femur & MB.R.2671 & e 2 & $\begin{array}{l}\text { Janensch (1961: fig. 18; tab. 13; } \\
\text { pl. 20, fig. 4) }\end{array}$ & \\
\hline Right humerus & MB.R.2656 & G 81 & Janensch (1961: tab. 4) & $\begin{array}{l}\text { Janensch (1961) lists a right humerus } \\
\text { "G } 91 \text { "; since the measurements are } \\
\text { identical to G } 81 \text {, this is probably a } \\
\text { typing error }\end{array}$ \\
\hline Right humerus & MB.R.2709 & $\mathrm{G}$ ? & & no exact field no. \\
\hline \multirow[t]{8}{*}{ Cranial caudal vertebrae } & - & K 8 & & \\
\hline & - & K 9 & & \\
\hline & - & K 11 & & \\
\hline & - & K 13 & & \\
\hline & - & K 16 & & \\
\hline & - & K? & & possibly $\mathrm{K} 10,12,14$, or 15 \\
\hline & - & $K ?$ & & possibly $\mathrm{K} 10,12,14$, or 15 \\
\hline & - & K 18 & & \\
\hline Right tibia & MB.R.2599 & K la & $\begin{array}{l}\text { Janensch (1961: 211; ins. K, fig. 3a-e; } \\
\text { tab. 15; pl. 21, fig. 2a-e) }\end{array}$ & $\begin{array}{l}\text { all K } 1 \text { found in articulation } \\
\text { (Janensch 1961: 214) }\end{array}$ \\
\hline Right fibula & MB.R.2626 & $\mathrm{K} 1 \mathrm{~b}$ & $\begin{array}{l}\text { Janensch (1961: 214; tab. 16; } \\
\text { pl. 21, fig. 3a-c) }\end{array}$ & \\
\hline Right astragalus & MB.R.2564 & $\mathrm{K} 1 \mathrm{c}$ & Janensch (1961: tab. 17) & \\
\hline Left tibia & MB.R.2594 & K 3 & & \\
\hline Right fibula & MB.R.2619 & NAGD 19 & & not in GTE field catalogue \\
\hline Right femur & MB.R.2663 & no 1 & Janensch (1961: tab. 13) & \\
\hline Left femur & MB.R.2670 & NW 4 & & not in GTE field catalogue \\
\hline Right astragalus & MB.R.2560 & Ob 5 & & \\
\hline Right pedal ungual 1.2 & MB.R.2317 & T 14 & & \\
\hline Left manual ungual 1.2 & MB.R.2304 & TE a & & not in GTE field catalogue \\
\hline Right metatarsal III & MB.R.2280 & Tec 42 & & not in GTE field catalogue \\
\hline Manual phalanx & MB.R.2298 & TL 35 & & \\
\hline Manual phalanx & MB.R.2299 & TL 45 & & \\
\hline Left astragalus & MB.R.2555 & TL 31 & & \\
\hline Left pedal ungual II.3 & MB.R.2315 & TL 14 & & \\
\hline \multirow[t]{3}{*}{ Distal caudal vertebrae } & - & Z 15 & Janensch (1929: 23; fig. 21a-b) & in $\mathrm{MB}$ exhibition \\
\hline & - & Z 27 & & \\
\hline & - & Z 37 & & \\
\hline Left fibula & MB.R.2616 & VI 2 & & \\
\hline Left humerus & MB.R.2646 & VIII 1 & $\begin{array}{l}\text { Janensch (1961: 188; tab. 4; } \\
\text { pl. 16, fig. 5) }\end{array}$ & $\begin{array}{l}\text { erroneously listed as right humerus (Ja- } \\
\text { nensch 1961: tab. 4) }\end{array}$ \\
\hline Right pubis & MB.R.2722 & $\mathrm{XI}$ a 10 & $\begin{array}{l}\text { Janensch (1961: 202; tab. 10; } \\
\text { pl. 19, fig. 2) }\end{array}$ & $\begin{array}{l}\text { referred to as "XI 10" in Janensch } \\
\text { (1961: tab. 10) }\end{array}$ \\
\hline
\end{tabular}


Appendix (continued)

\begin{tabular}{|c|c|c|c|c|}
\hline Specimen & Catalogue no. & $\mathrm{FN}$ & References & Comments \\
\hline Complete right pes & MB.R.2371 & XIII 10 & $\begin{array}{l}\text { Janensch (1961: 223-227; fig. 26; } \\
\text { ins. P, figs 6-10; ins. Q, fig. B; } \\
\text { pl. 23, fig. 7) }\end{array}$ & 15 elements in total \\
\hline Left humerus & MB.R.2648 & XVI 66 & & \\
\hline Left humerus & MB.R.2708 & XVI 64 I & & \\
\hline Right humerus & MB.R.2632 & XVI 107 o & & \\
\hline Left humerus & MB.R.2643 & XVI 1280 & & \\
\hline Left metatarsal I & MB.R.2400 & XVI 21 & & \\
\hline Right metatarsal I & MB.R.2286 & XVI 28 & & \\
\hline Right pedal ungual II.3 & MB.R.2327 & XVI $20 \mathrm{c}$ & & \\
\hline Left femur & MB.R.2637 & XVII 5 & & \\
\hline $\begin{array}{l}\text { Complete left pes, } \\
\text { astragalus }\end{array}$ & MB.R.2370 & Nr. 28 & $\begin{array}{l}\text { Janensch (1961: 223-227; fig. 25; ins. P, } \\
\text { figs 1-5; ins. Q, fig. A; pl. 23, fig. 6) }\end{array}$ & \\
\hline Left pedal phalanx I.1 & MB.R.2300 & Nr. 68 & & \\
\hline Left femur & MB.R.2660 & Nr. 76 & Janensch (1961: tab. 13) & \\
\hline Left tibia & MB.R.2573 & Nr. 77 & & \\
\hline Right astragalus & MB.R.2566 & Nr. 79 & Janensch (1961: tab. 17) & \\
\hline Distal caudal vertebra & - & - & & labeled "LJC-BDC Apr. 98" \\
\hline Left astragalus & MB.R.2567 & - & & \\
\hline Left pedal ungual & MB.R.2328 & - & & \\
\hline \multicolumn{5}{|l|}{ Upper Transitional Sands: } \\
\hline Left fibula & MB.R.2614 & F 4 & Janensch (1961: tab. 16) & \\
\hline Left ulna & MB.R.2585 & H 7 & Heinrich (1999: 44; fig. 12) & \\
\hline Right radius & MB.R.2617 & H 6 & Heinrich (1999: 44; fig. 12) & labeled as fibula \\
\hline Left pubis & - & H 9 & Heinrich (1999: 44; fig. 12) & \\
\hline Right pubis & - & $\mathrm{H} 10$ & Heinrich (1999: 44; fig. 12) & \\
\hline Left femur & MB.R.2685 & $\mathrm{H} 4$ & Heinrich (1999: 44; fig. 12) & \\
\hline Right femur & MB.R.2667 & H 1 & Heinrich (1999: 44; fig. 12) & \\
\hline Left tibia & MB.R.2579 & H 8 & Heinrich (1999: 44; fig. 12) & \\
\hline Right tibia & MB.R.2578 & $\mathrm{H} 2$ & Heinrich (1999: 44; fig. 12) & \\
\hline Left fibula & MB.R.2612 & H 3 & Heinrich (1999: 44; fig. 12) & \\
\hline Right fibula & MB.R.2611 & H 5 & Heinrich (1999: 44; fig. 12) & \\
\hline Left premaxilla & MB.R.2346 & Ki 126 & Janensch (1935-36: 221-222) & \\
\hline Right premaxilla & MB.R.2343 & Ki 125 & $\begin{array}{l}\text { Janensch (1929: fig. 3); Janensch } \\
\text { (1935-36: 221-222; figs 81-84) }\end{array}$ & \\
\hline Left maxilla & MB.R.2345 & Ki 127 & $\begin{array}{l}\text { Janensch (1929: fig. 5); Janensch } \\
\text { (1935-36: 223-224; figs 87-88) }\end{array}$ & $\begin{array}{l}\text { erroneously referred to as } \\
\text { "ki 125" (Janensch 1929, 1935-36) }\end{array}$ \\
\hline Right partial maxilla & MB.R.2350 & Ki 128 & Janensch (1935-36: 223) & three fragments \\
\hline Distal caudal vertebrae & - & Ki 75-77 & & \\
\hline Left humerus & MB.R.2653 & Ki 3 & $\begin{array}{l}\text { Janensch (1961: 188; tab. 4; pl. 16, } \\
\text { fig. 7) }\end{array}$ & \\
\hline Left humerus & MB.R.2639 & Ki 68a & $\begin{array}{l}\text { Janensch (1961: 188; tab. 4; pl. 16, } \\
\text { fig. 6) }\end{array}$ & identical with Ki 68 (Janensch 1961) \\
\hline Left ulna & MB.R.2604 & Ki 69a & Janensch (1961: tab. 6; pl. 17, fig. 2a-b) & identical with Ki 69 (Janensch 1961) \\
\hline Left radius & MB.R.2621 & Ki 70a & $\begin{array}{l}\text { Janensch (1961: 192; tab. 7; pl. 17, } \\
\text { fig. 4) }\end{array}$ & $\begin{array}{l}\text { identical with Ki } 70 \text { (Janensch 1961), } \\
\text { erroneously labeled as "Ki 69"" }\end{array}$ \\
\hline Right ulna & MB.R.2602 & Ki 63 & $\begin{array}{l}\text { Janensch (1961: 191; tab. 6; pl. 17, } \\
\text { fig. 3) }\end{array}$ & \\
\hline Right pubis & MB.R.2735 & Ki 13 & $\begin{array}{l}\text { Janensch (1961: 202; tab. 10; pl. 19, } \\
\text { fig. 3) }\end{array}$ & $\begin{array}{l}\text { erroneously referred to as left pubis } \\
\text { (Janensch 1961: 202) }\end{array}$ \\
\hline Left ischium & - & Ki 14 & & \\
\hline
\end{tabular}


Appendix (continued)

\begin{tabular}{|c|c|c|c|c|}
\hline Specimen & Catalogue no. & FN & References & Comments \\
\hline Left femur & MB.R.2665 & Ki 4 & Janensch (1961: fig. 20) & \\
\hline Right femur & MB.R.2661 & Ki 2 & Janensch (1961: tab. 13) & \\
\hline Left femur & MB.R.2662 & Ki 8 & Janensch (1961: tab. 13) & \\
\hline Right femur & MB.R.2666 & Ki 10 & & \\
\hline Left femur & MB.R.2641 & Ki 71a & $\begin{array}{l}\text { Janensch (1961: 209; tab. 13; } \\
\text { pl. 20, fig. 5) }\end{array}$ & \\
\hline Left tibia & MB.R.2597 & Ki $72 a$ & Janensch (1961: tab. 15) & \\
\hline Left tibia & MB.R.2576 & Ki 11 & Janensch (1961: tab. 15) & \\
\hline Left tibia & MB.R.2581 & Ki 66 & & \\
\hline Right tibia & MB.R.2596 & Ki 5 & & \\
\hline Left fibula & MB.R.2615 & Ki 65 & $\begin{array}{l}\text { Janensch (1961: 214; tab. 16; } \\
\text { pl. 21, fig. 5) }\end{array}$ & \\
\hline Left pedal ungual I.2 & MB.R.2316 & Ki 9 & & \\
\hline Left humerus & MB.R.2654 & IX 94 & Heinrich (1999: 45-46; fig. 13) & \\
\hline Right humerus & MB.R.2644 & IX k 11 & Heinrich (1999: fig. 13) & \\
\hline Right humerus & MB.R.2645 & IX 01 & Heinrich (1999: fig. 13) & \\
\hline Right humerus & MB.R.2647 & IX t 1 & Heinrich (1999: fig. 13) & \\
\hline Right metacarpal III & MB.R.2282 & $1 x+3$ & & erroneously labeled "IX b 3" \\
\hline Right femur & MB.R.2700 & IX 1a & & \\
\hline Right metatarsal I & MB.R.2284 & IX t 4 & & \\
\hline Left humerus & MB.R.2642 & $\mathrm{XI}$ a 7 & Janensch (1961: tab. 4) & \\
\hline Left humerus & MB.R.2649 & XV 8 & & \\
\hline Left humerus & MB.R.2650 & XV 50 & & \\
\hline Left humerus & MB.R.2651 & $\mathrm{XV}$ a 17 & & \\
\hline Left humerus & MB.R.2652 & $X V ?$ & & \\
\hline Right metacarpal III & MB.R.2283 & XV 44 & & \\
\hline Left metacarpal IV & MB.R.2285 & XV 43 & & \\
\hline \multicolumn{5}{|l|}{ Middle Saurian Beds: } \\
\hline Braincase & MB.R.2388 & dd 130 & $\begin{array}{l}\text { Janensch (1935-36: 214-221; } \\
\text { figs } 75-78)\end{array}$ & \\
\hline Braincase with skull roof & MB.R.2387 & dd 316 & $\begin{array}{l}\text { Janensch (1935-36: 214-221; } \\
\text { figs } 70-74)\end{array}$ & \\
\hline Left premaxilla & MB.R.2344 & dd 416 & $\begin{array}{l}\text { Janensch (1935-36: 221-222; } \\
\text { figs } 85-86 \text { ) }\end{array}$ & \\
\hline Left prefrontal & MB.R.2349 & dd 517 & Janensch (1935-36: 221; figs 79-80) & \\
\hline Left dentary & MB.R.2348 & dd 518 & $\begin{array}{l}\text { Janensch (1935-36: 224-225; } \\
\text { figs } 92-93 \text { ) }\end{array}$ & \\
\hline Atlantal intercentrum & MB.R.2389 & $\mathrm{dd} ?$ & & \\
\hline \multirow[t]{2}{*}{ Caudal vertebrae } & MB.R.2959 & dd 169 & & \\
\hline & MB.R.2960 & dd 168 & & \\
\hline Right ilium & MB.R.2716 & St 243 & Janensch (1961: 200) & erroneously labeled "St 234" \\
\hline Right fibula & MB.R.2623 & St 61 & Janensch (1961: tab. 16) & \\
\hline Right metatarsal II & MB.R.2278 & St 905 & Janensch (1961: 223; ins. P, fig. 11a-c), & erroneously labeled as metatarsal III \\
\hline Left metatarsal III & MB.R.2279 & St 307 & Janensch (1961: 223; ins. P, fig. 12a-c) & \\
\hline Left metatarsal V & MB.R.2281 & St 108 & & \\
\hline
\end{tabular}

